\title{
Corporate Brand Experience as a New Construct and Its Effects on Employees' Corporate Brand Pride and Brand-Supporting Behaviours
}

\author{
Philipp Egeler ${ }^{1}$, Fabian Abed ${ }^{1} \&$ Marion Büttgen ${ }^{1}$ \\ ${ }^{1}$ Department for Corporate Management, University of Hohenheim, Stuttgart, Germany \\ Correspondence: Fabian Abed, Department for Corporate Management, University of Hohenheim, Stuttgart, \\ Germany. E-mail: f_abed@uni-hohenheim.de
}

Received: November 2, 2021

Accepted: December 16, 2022

Online Published: January 27, 2022

doi:10.5539/ijbm.v17n3p39

URL: https://doi.org/10.5539/ijbm.v17n3p39

\begin{abstract}
Employee corporate brand experience is conceptualised as any contact employees have with a corporate brand along the wide range of brand touch-points. To investigate this topic, this paper provides two studies. In Study 1 $(\mathrm{n}=195)$, an employee corporate brand experience scale for direct and indirect corporate brand experiences (DCBEs and ICBEs, respectively) has been developed and validated. In doing so, this paper shows that these scales are distinct from existing experience measures in consumer and organisational behaviour research. Study 2 investigates how these different types of brand experiences generate employee corporate brand pride and turn employees into brand champions. A multivariate data analysis technique (partial least squares) is used to analyse data from 283 employees in Germany. By building on and advancing the assumptions of affective events theory, Study 2 shows that only ICBEs trigger emotional and attitudinal brand pride in turn affect brand-supporting behaviours.
\end{abstract}

Keywords: Internal branding, corporate brand experience, brand pride, brand commitment, brand-supporting behaviours

\section{Introduction}

Internal branding refers to focussed organisational efforts to promote a brand to employees, thereby motivating them to strengthen the corporate brand and become brand ambassadors (Morhart, Herzog, \& Tomczak, 2009). Since internal branding has a major influence on brand performance (Punjaisri, Wilson, \& Evanschitzky, 2008) and not only motivates employees to exert brand building behaviours (Morhart et al., 2009) but even more leads to enhanced customer related outcomes (Backhaus, 2016), companies worldwide are increasingly investing vast amounts of money and resources in internal branding efforts (e.g. Caterpillar and Mercedes-Benz) (Baumgarth \& Schmidt, 2010). For example, in recent years, Mercedes-Benz has started several long-term initiatives for employees and managers, including a virtual brand academy on their intranet and a Mercedes-Benz brand book specifically designed for managers. The virtual brand academy includes an interactive training tool for employees (Pearlman, 2010), and the book, which was given to 13000 managers, recounts the pioneering work of the Mercedes-Benz founder and communicates the meaning of brand values to managers in an emotionally moving context. In addition, training workshops complement the international brand ambassador programme. Such branding initiatives are relevant to brand success because employees are said to reinforce an organisation's brandbuilding efforts (Löhndorf \& Diamantopoulos, 2014), both on the job (in-role behaviour) and off the job. Furthermore, these efforts come with behaviours that go beyond prescribed roles (extra-role behaviour), for example, as brand representatives to friends, family, customers or even potential hires (Bloemer, 2010; Löhndorf \& Diamantopoulos, 2014).

Internal branding research applies several levers for turning employees into brand ambassadors. For example, Morhart et al. (2009) investigated the role of leadership for accomplishing this. In another study, the employee brand fit, brand knowledge or belief in the brand was investigated (Löhndorf \& Diamantopoulos, 2014) as potential sources of employee brand-supporting behaviours. However, to date, the employee corporate brand experience has widely been neglected as a potential antecedent of employee brand-supporting behaviours. This negligence is interesting because internal branding emerged from consumer branding. In consumer branding, the power of experience with a brand or company and understanding of how consumers experience brands (Klein, Falk, Esch, \& Gloukhovtsev, 2016) are well documented and play crucial roles in developing effective marketing strategies 
(Verhoef et al., 2009). Hence consumer research is especially investigating how to establish an emotional bond between the brand and customer (Brakus, Schmitt, \& Zarantonello, 2009). One potential source for strengthening the emotional bond between employees and the brand is employee brand-related experience. Experiences are especially relevant as - according to affective events theory (AET) - they trigger emotions (Weiss \& Cropanzano, 1996). As a result, emotionally attached employees are more likely to exert brand citizenship behaviour (Piehler, King, Burmann, \& Xiong, 2016). Moreover, in the same way that 'consumers look for brands that provide them with unique and memorable experiences', corporate brands that manage their employee related experiences could attract potential hires (Zarantonello \& Schmitt, 2010, p. 532). One reason that internal branding research has hitherto lacked evidence regarding the role of brand-related experiences may be the lack of an employee corporate brand experience scale. For this reason, the aim of this study is to define, clarify, conceptualise and examine the role of brand-related experiences, especially by focussing on the question of how employees can be turned into brand champions. In this paper, using a multivariate data analysis technique (partial least squares, PLS), both the conceptual development of a new employee corporate brand experience scale and an empirical analysis of the consequences of employees' corporate brand experience is presented.

For defining and conceptualising employee corporate brand experience and its underlying dimensions, at first a literature review of consumer and marketing research was conducted. Then, an employee corporate brand experience scale that is different from related constructs, such as existing brand experience scales from consumer or organisational research (Brakus et al., 2009; Edwards \& Edwards, 2013) is developed. Next, the scales were tested using standard validation procedures for scale development. Furthermore, this study tested whether corporate brand experience elicits emotional (corporate brand) pride, responding to calls for further research (Helm, 2012; Kraemer, Gouthier, \& Heidenreich, 2016; Kraemer, Weiger, Gouthier, \& Hammerschmidt, 2020). Since AET postulates that emotions arise from experiences, this theory was used as a theoretical groundwork.

Overall, the present study adds several contributions to the existing literature. First, it is the only research so far to explicitly define, measure and examine the consequences of employees' corporate brand experience. In doing so, this paper enrich brand experience literature as new conceptual work in this field is quite rare (e.g Andreini, Pedeliento, Zarantonello, \& Solerio, 2018; Zha, Melewar, Foroudi, \& Jin, 2020). Drawing on and adapting the concept of customer brand touch-points both direct and indirect corporate brand experiences (DCBEs and ICBEs, respectively) have been implemented as work events. Thereby study 2 broadens the theoretical view of AET as no prior AET studies have investigated whether work events could be either direct or indirect. Second, by investigating how corporate brand pride could be triggered, study 2 shows that DBCE and IBCE are not equally relevant in building corporate brand pride. The findings presented illustrate that ICBE triggers brand pride, which in turn, increases brand citizenship behaviour and has a major effect on how branding activities should be designed. Finally, as the third contribution, this paper shows that corporate brand pride is an important driver in brandbuilding behaviours. Consequently, against the backdrop of prior research - which predominantly emphasises brand commitment as a central driver of brand-supporting behaviour-study 2 identifies the psychological mechanisms of reinforcing brand building. In contrast to prior studies (e.g. Helm, Renk, \& Mishra, 2016), an explanation is provided for the underlying effects (especially antecedents) of corporate brand pride by applying AET. However, based on the findings of the studies performed, this research enriches the current view of this theory by proving that its assumptions are also applicable to an internal branding context and that it can serve as a framework for brand-building behaviours.

\section{Study 1: Developing and Validating the Corporate Brand Experience Scale}

\subsection{Literature Review}

In consumer marketing research, 'marketers recognise the power of experience[s] [...] to create value for consumers' (Schouten, McAlexander, \& Koenig, 2007, p. 357) and to establish an emotional bond between the brand and customer (Brakus et al., 2009). Consumer research scholars have identified a multitude of possible experiences individuals can have. In line with Zarantonello and Schmitt (2010), these can include the product (Hoch, 2002), brand (Brakus et al., 2009), shopping (Klein et al., 2016), customer (Biedenbach \& Marell, 2010), online brand (Morgan-Thomas \& Veloutsou, 2013) or even corporate brand experience (Hamzah, Syed Alwi, \& Othmann, 2014).

Previous internal branding research has lacked evidence regarding the role of brand-related experiences, especially in turning employees into brand ambassadors. This is interesting because the emotional bond between employees and a (corporate) brand has been a major topic in several brand and organisational studies (e.g. Burmann, Zeplin, $\&$ Riley, 2009). These studies have frequently investigated the antecedents and outcomes of brand commitment. Yet, none of them alluded to employee brand-related experiences. In a recent investigation the role of emotions in 
decision making on employer brands using insights from functional magnetic resonance imaging, Rampl et al. (2014) argued that generating emotional experiences with the organisation could become increasingly important for an employee - brand context; thus, this research tries to fill the gap in the literature by considering this topic.

\subsection{Corporate Brand Experience: Conceptual Definition}

In the absence of a considerable and diverse discussion of employee (corporate) brand experience in internal branding or marketing research (e.g. Andreini et al., 2018), a new corporate brand experience construct using the insights from previously performed marketing and consumer research is conceptualised. According to customer marketing research, 'brand experience includes the spectrum of events or interactions that a customer has with a brand. Thus, a brand experience can include customers direct use of a product and/or service, as well as indirect brand images, associations, and events' (Cliffe \& Motion, 2005, p. 1069). Product experiences can therefore either be direct respectively product-related (e.g. if consumers have physical contact with the product) or indirect (e.g. if the company is virtually presented in an advertisement) (Kempf \& Smith, 1998; Hoch, 2002; Brakus et al., 2009). These experiences can also occur during the interaction with the brand's products . For e.g. the shopping or service experience occurs when a consumer interacts with the employees or physical environment of a store and its policies or practices (Hui \& Bateson, 1991; Kerin, Jain, \& Howard, 1992; Holbrook, 2000). Based on this, we acknowledge that brand experiences can either be tangible or intangible.

In line with prior conceptualisations from consumer and internal branding research employees can have both direct (product-related) and indirect (non-product-related) experiences with a corporate brand (e.g. Iglesias, Markovic, \& Rialp, 2019). Based on this assumption, the brand experience is not only about experience the companies' products but also about experiencing what a brand stands for, the values and norms it is based on and which attributes (in the case of a product brand) it offers. Here, direct experiences occur when employees experience the products from the company they work for, for example, when employees work for an automobile company and use a company car to drive to business appointments (i.e. direct organisational corporate brand experience). Direct experiences can also occur when employees experience the brand's products in private settings like using a refrigerator at home (i.e. direct private corporate brand experience). Similar to the consumer context, in which direct experiences mostly occur during interactions with brand touch-points, such as the brand's physical elements (e.g. packaging) (Klein et al., 2016), employees' DCBEs are shaped by experiencing the concrete attributes of the brand's products. Hence, DCBE is conceptualised as a construct comprising two dimensions, namely, organisational and private product-related corporate brand experiences (see Fig 1). In a consumer context, definitions of brand experience range from detailed descriptions to more general definitions, such as 'internal and subjective direct $[\ldots]$ or indirect contact with the company', where direct experiences occur during the product use and indirect experiences for example involves encounters with brand representatives (Meyer \& Schwager, 2007, p. 118). Consequently, we define DCBE as an employee's subjective experience of the brand benefits through any product-related direct contact with the corporate brand products occurring in an organisational or private setting.

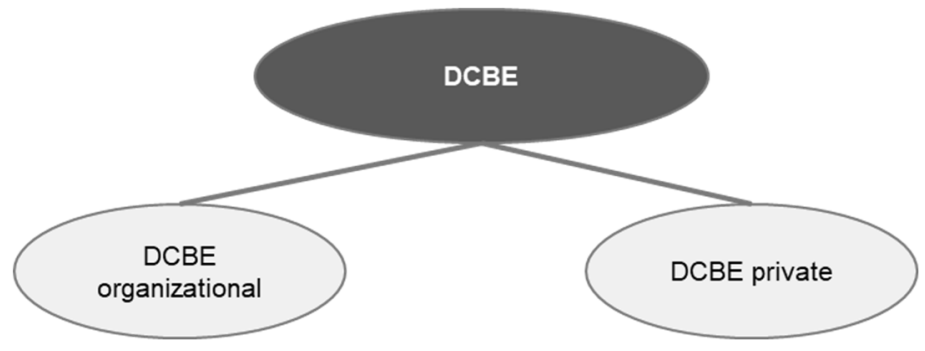

Figure 1. Direct corporate brand experience

Besides experiencing the (corporate) brand through the companies' products employees of a company can also experience the brand and its values indirectly or non-product-related. Thereby, various brand touch-points exist and need to be managed to deliver a consistent (corporate) brand experience in an employee context-likewise in consumer marketing (Mosley, 2007). Following this assumption and drawing on branding literature employee brand touch-points can be mainly divided into the following dimensions: people-related (e.g. supervisors, colleagues, friends and family), media-related (e.g. internal and external communications) and HR-related (e.g. empowerment, hiring, leadership, training) (Burmann et al., 2009; Burmann \& König, 2011; Punjaisri \& Wilson, 2011; Chiang, Chang, Han, \& Mcconville, 2013). With regard to people-related aspects a reference is often made to the importance of managers or leaders to exemplify the values of a (corporate) brand and demonstrate the values 
internally and externally by acting as role models (Mosley, 2007; Morhart et al., 2009). In a similar way, employees can experience the (corporate) brand and its values through external feedback, e.g. through friends and acquaintances. Media-related elements such as internal and external communications are also frequently included in models of (internal) branding as both forms of communication significantly shape employees' perceptions of the (corporate) brand and its values (e.g. Burmann \& König, 2011). Brand centered HR activities such as (brand) empowerment, (brand) incentives, (brand) selective hiring, (brand) leadership or (brand) training exhibit further brand touch-points of employees (Burmann et al., 2009; Burmann \& König, 2011; Punjaisri \& Wilson, 2011; Chiang et al., 2013).

Complementing the construct development and preempting the validation section, various brand-related HR practices were included in the pre-test (empowerment, information sharing, selective hiring, training, competitive compensation, job security and leadership). However, none of these HR practices revealed to be part of the nonproduct-related brand experience dimensions. This might relate to the fact that core aspects of branding such as brand communication refer to the brand's identity (e.g. values) itself and employees consider these facets as closer connected to the corporate brand compared to HR-related facets. This potential explanation is in line with findings of Burmann et al. (2009) who showed that brand centered HR practices exhibit lower effects on brand commitment compared to internal brand communication focusing on (brand) values. Thus, ICBE describes brand experiences through internal and external communication, colleagues, supervisors, and even feedback from friends and family with the focus on experiencing the values of the corporate brand. Consequently, we define ICBE as the employees' subjective experience of brands benefitting from any non-product-related indirect contact with the corporate brand, which is initiated by colleagues, supervisors, internal and external communication and external feedback from friends and family (see Fig 2).

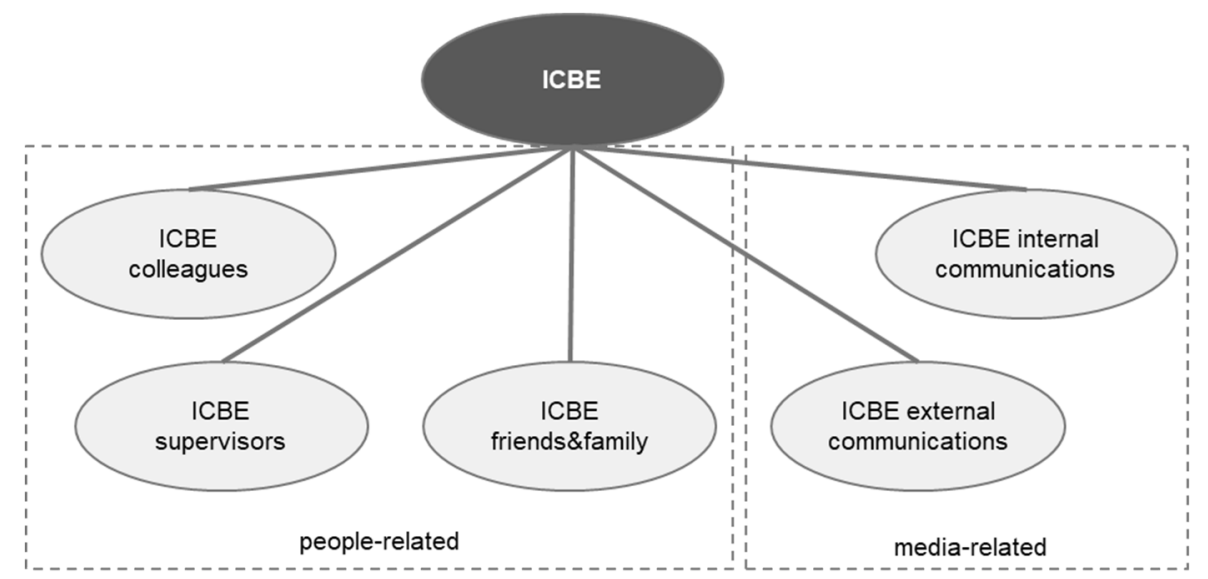

Figure 2. Indirect corporate brand experience

\subsection{Corporate Brand Experience and Related Constructs}

Like existing brand experience constructs in consumer research, employee corporate brand experience involves both direct and indirect experiences. However, the employee corporate brand experience differs from concepts like product (Hoch, 2002), brand (Brakus et al., 2009) or corporate brand experience (Hamzah et al., 2014) because the employee is the central aspect and not the costumer (as it is with brand experience in consumer marketing research).

In addition to physical contact with the brand's products, employees have a psychological contract with the employing organisation. This contract consists of certain beliefs about the employee-employer reciprocal obligations (Morrison \& Robinson, 1997). According to this, and in line with the definition of an employer brand provided by Ambler and Barrow (1996, p. 187) as the 'package of functional, economic and psychological benefits provided by employment', one may argue that experiencing a corporate brand is also characterised by employer brand-related predictors, such as the provision of unique employment experiences (Edwards \& Edwards, 2013). According to Edwards and Edwards (2013), such predictors can be tangible or intangible, which is in line with the terms direct and indirect, respectively, in our research. Furthermore, they state that a unique employment experience consists of terms and conditions that the employer offers, such as the compensation package, autonomy or developmental opportunities. This is in line with Backhaus (2016) who show that objective information about the work environment are relevant in an employer branding context, even more when the brand experience is 
consistent with the estimated brand experience. According to Backhaus (2016, p. 193), 'the employer brand makes a promise to its prospective and current employees about the experience they will have in the organization'. In contrast to the study of Edwards and Edwards (2013) and their unique employment experience scale, the developed corporate brand experience construct in this paper focusses not only on the experiences provided by the organisation as an employer (brand) but also the experiences that employees can have by using the products their companies offer and experiencing the symbolic brand benefits, such as the values a company stands for.

As the corporate brand experience scale in this paper concentrates on the exposure of utilitarian attributes of the corporate brand and relevant brand-employee stimuli, study 1 additionally includes the most highly cited and wellknown brand experience scale developed by Brakus et al. (2009). This paper focusses on the major sources of an employee's subjective and internal response to DCBEs and ICBEs. In contrast, Brakus et al.'s (2009) scale focusses on subjective and internal consumer responses evoked by brand-related stimuli, considering sensory, affective, behavioural or intellectual consumer reactions.

\subsection{Scale Development}

For the corporate brand experience, as a novel construct in internal branding research, inspired by previous research focusing on the consumer context (Brakus et al., 2009), a new measure is developed and conceptualised as a two-dimensional construct comprising direct and indirect experiences. Here, established procedures were followed as described in the previous literature (Churchill, 1979; Crawford \& Kelder, 2018).

\subsubsection{Item generation and reduction}

Based on 15 exploratory in-depth interviews with professionals of diverse sectors and the comprehensive literature search that has been conducted regarding branding and concepts related to (corporate brand) experience, an initial item pool of 75 scale items intended to cover multiple aspects of the corporate brand experience was created. Various brand touch-points an employee can have with the corporate brand were included (e.g. Burmann et al., 2009; Burmann \& König, 2011; Punjaisri \& Wilson, 2011; Chiang et al., 2013). After generating this initial item pool, all the items were conceptually (pre-)grouped according to the pre-identified brand touch-points to simplify the following review by marketing research scholars. These touch-points or dimensions represent the relevant aspects of (internal)branding literature and are important in an employee brand context. Next, several marketing research scholars (two marketing faculty members and 11 doctoral students) - who were familiar with the branding literature but unaware of the specific focus of this research project - reviewed the item selection and evaluated the content validity of each item based on the definition of the corporate brand experience. The wording was slightly adapted, and redundant items were eliminated. As a result, a semi-final set of 39 items remained.

\subsubsection{Initial Validation (pre-test)}

The item set was first intensively tested and pre-validated in a pre-test consisting of 88 employees working for product-based $(42 ; 47.7 \%)$ and service-based $(46 ; 52 \%)$ companies. Of all the respondents, $54(61.4 \%)$ were female and $34(38.6 \%)$ were male. Furthermore, 64 (72.7\%) were young professionals with less than six years of work experience. After the descriptive analysis of the data, exploratory factor analysis (EFA; oblimin rotation) was conducted. Oblique rotation was chosen at this early stage due to its higher sensitivity in highlighting correlations among factors, compared to orthogonal rotation technique (Fabrigar, Wegener, MacCallum, \& Strahan, 1999). The results showed that the ICBE scale revealed a two-factor structure (eigenvalue $>1$ ) explaining $77.60 \%$ of the total variance $\left(\mathrm{KMO}=0.76, \chi^{2}=527.56, d f=55, p=0.00\right)$. Next, analysis of the ICBE scale comprised five factors with eigenvalues greater than 1 . These factors explained $87.03 \%$ of the total variance $\left(\mathrm{KMO}=0.82, \chi^{2}=\right.$ 1967.91, $d f=171, p=0.00$ ). Together, obtained data were found appropriate for factor analysis after calculating the fulfilled relevant criteria with the Kaiser-Meyer-Olkin (KMO) coefficient and execution of the Bartlett test of sphericity (Field, 2005).

As a second step, the internal reliability of each corporate brand experience dimension was assessed by calculating Cronbach's $\alpha$. All the values exceeded the recommended criteria of 0.7 (Nunnally, 1978). The results were as follows: $\mathrm{DCBE}$ organisational $=0.84, \mathrm{DCBE}$ private $=0.97, \mathrm{ICBE}$ supervisors $=0.94, \mathrm{ICBE}$ colleagues $=0.95$, ICBE friends \& family $=0.85$, ICBE internal communication $=0.94$, and ICBE external communication $=0.94$. An analysis of the item-to-total correlations revealed that only one item (Item 1, DCBE organisational) did not meet the threshold of 0.50 (Hair et al., 2010). Thus, this item was eliminated from further studies.

As the third step, confirmatory factor analysis (CFA) was used for assessing the dataset of the pre-test. The aim of the analysis was identifying potential issues regarding low factor loadings at the early stage of this research. The results showed adequate values (especially for the small sample size) exceeding mostly the recommended threshold of 0.7 (Bagozzi \& Yi, 1988; Hair, Black, \& Babin, 2010)—DCBE organisational = 0.46-0.98, DCBE 
private $=0.86-0.97, \mathrm{ICBE}$ supervisors $=0.88-0.91, \mathrm{ICBE}$ colleagues $=0.83-0.95, \mathrm{ICBE}$ friends $\&$ family $=0.66-$ 0.94 , ICBE internal communication $=0.75-0.98$, and ICBE external communication $=0.81-0.98$. Based on the DCBE organisational and ICBE friends \& family, the wording was adapted slightly. The brand centered HR activities - as described in section 'corporate brand experience: conceptual definition'-have been excluded from further research for the following reasons. Factor analyses revealed that the brand centered HR activities (e.g. brand empowerment, brand selective hiring, brand training and brand competitive compensation) did not appear as distinct factors performing EFA (varimax and oblique rotation). A further analysis of the inter-item-correlations depict very low values compared to the other ICBE dimensions. Additionally, CFA results exhibit inadequate factor loadings with regard to the HR-related aspects compared to the other ICBE aspects.

\subsubsection{Validation of the Measurement Model}

The validation dataset was collected to confirm the measurement model and its validity. The data were collected from 195 professionals working for German companies. Of the respondents, 78 (40.0\%) were female and 117 $(60.0 \%)$ were male. Almost half the respondents $(45.6 \%)$ were senior professionals with more than six years of work experience. In addition, $157(80.5 \%)$ respondents were working for organisations with more than 500 employees. Most of the employees held a university degree $(157 ; 80.5 \%)$.

Prior to EFA, the appropriateness for factor analysis was examined. Here, the KMO coefficient was calculated and the Bartlett test of sphericity was performed. The results indicated that the data were appropriate for factor analysis $\left(\mathrm{KMO}=0.90, \chi^{2}=6260.79, d f=406, p=0.00\right)$ (Field, 2005). Then, EFA was conducted using oblique rotation (oblimin). The results showed that the corporate brand experience scale comprised seven factors with eigenvalues greater than 1. In the next step, the internal reliability of each corporate brand experience dimension was assessed by calculating Cronbach's $\alpha$. All the obtained values exceeded the recommended criteria of 0.7 (Nunnally, 1978), with the following results: DCBE organisational $=0.89, \mathrm{DCBE}$ private $=0.97$, ICBE supervisors $=0.95, \mathrm{ICBE}$ colleagues $=0.91$, ICBE friends $\&$ family $=0.94$, ICBE internal communication $=0.90$, and ICBE external communication $=0.94$. Then, analysis of the item-to-total correlations revealed that all the items reached the threshold of 0.50 (Hair et al., 2010).

The following step involved CFA using AMOS 24 to assess the dimensionality, reliability and validity of the developed scale. First, a model in which all the items loaded on a single corporate brand experience construct (first-order one-factor model) was analysed, followed by the analysis of a one-factor model with seven subdimensions (second-order) and a two-factor model with seven subdimensions (second-order) as well as a nullmodel. CFA showed that the two-factor model with seven subdimensions (second order) was the most optimal one (see Tab. 1). The fit measures comparative fit index (CFI), normed fit index (NFI), root mean square error of approximation (RMSEA) and standardized root mean square residual (SRMR) for this model suggested a good fit $(\mathrm{CFI}=0.95, \mathrm{NFI}=0.90, \mathrm{GFI}=0.82, \mathrm{RMSEA}=0.06, \mathrm{SRMR}=0.08)$. Second, the reliability of each scale included in the validation study was assessed by calculating the composite reliability $(\mathrm{CR})$ and average variance extracted (AVE). The CR for each construct was greater than 0.70, and the AVE was greater than 0.50 , thereby exceeding the common threshold as shown in Tab 2 (Bagozzi \& Yi, 1988; Hair et al., 2010). Then, the factor loadings were examined as the third step The results showed that they were all statistically significant. Except for two items (Item 1, ICBE internal communications; Item 5, DCBE organisational), all factor loadings were greater than 0.70 , indicating convergent validity. As the values were close to the threshold of 0.70 , it was decided to keep them. Finally, in the fourth step, the discriminant validity was assessed by comparing the AVE of each factor with the shared variance between each pair of factors (Fornell and Larcker, 1981). The results showed that the AVE levels for all constructs included in Study 1 were higher than all the combinations of shared variance (see Tab. 3). 
Table 1. Model comparison (validation of study 1)

\begin{tabular}{lccccc} 
& CFI & NFI & GFI & RMSEA & CMIN/df \\
\hline Two-factor model with 7 subdimensions $\left(2^{\text {nd }}\right.$ order $)$ & 0.95 & 0.90 & 0.82 & 0.06 & 1746 \\
One-factor model with 7 subdimensions $\left(2^{\text {nd }}\right.$ order $)$ & 0.93 & 0.88 & 0.78 & 0.07 & 2153 \\
Null model & 0.89 & 0.84 & 0.69 & 0.09 & 2782 \\
One-factor model & 0.44 & 0.42 & 0.34 & 0.21 & 10267 \\
\hline
\end{tabular}

Notes: $\mathrm{CFI}=$ comparative fit index, $\mathrm{NFI}=$ normed fit index, GFI = goodness of fit index, RMSEA = root mean square error of approximation, $\mathrm{CMIN} / \mathrm{df}=$ relative chi-square .

Table 2. Mean, standard deviation, scale reliability and AVE (validation of study 1)

\begin{tabular}{lllll}
\hline & Mean & SD & CR & AVE \\
\hline 1. DCBE organisational & 3.65 & 1.07 & 0.89 & 0.63 \\
2. DCBE private & 2.88 & 1.44 & 0.97 & 0.87 \\
3. ICBE colleagues & 3.22 & 0.87 & 0.92 & 0.74 \\
4. ICBE supervisors & 3.14 & 1.08 & 0.95 & 0.85 \\
5. ICBE internal communications & 3.50 & 1.03 & 0.91 & 0.72 \\
6. ICBE external communications & 2.77 & 1.23 & 0.94 & 0.80 \\
7. ICBE friends \& family & 3.45 & 1.17 & 0.94 & 0.85 \\
8. Employment experience & 3.24 & 1.08 & 0.84 & 0.57 \\
9. Brand experience (sensory) & 2.88 & 1.24 & 0.95 & 0.86 \\
10. Brand experience (affective) & 2.96 & 1.23 & 0.89 & 0.73 \\
$\begin{array}{l}\text { 11. Brand experience (behavioural) } \\
\text { 12. Brand experience (intellectual) }\end{array}$ & 2.29 & 1.17 & 0.93 & 0.82 \\
$\begin{array}{l}\text { 13. WOM } \\
\text { 14. Attitudinal corporate brand pride }\end{array}$ & 2.50 & 1.05 & 0.91 & 0.77 \\
\hline
\end{tabular}

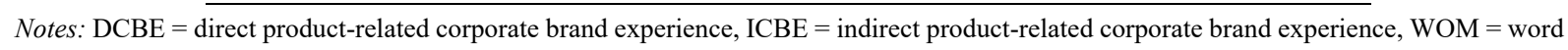
of mouth, $\mathrm{SD}=$ standard deviation, $\mathrm{CR}=$ composite reliability, $\mathrm{AVE}=$ average variance extracted. 
Table 3. Correlations (validation of study 1)

\begin{tabular}{|c|c|c|c|c|c|c|c|c|c|c|c|c|c|c|}
\hline & 1 & 2 & 3 & 4 & 5 & 6 & 7 & 8 & 9 & 10 & 11 & 12 & 13 & 14 \\
\hline \multirow[t]{2}{*}{ 1. DCBE organisational } & 0.8 & & & & & & & & & & & & & \\
\hline & 0 & & & & & & & & & & & & & \\
\hline \multirow[t]{2}{*}{ 2. DCBE private } & 0.4 & 0.9 & & & & & & & & & & & & \\
\hline & 0 & 3 & & & & & & & & & & & & \\
\hline \multirow[t]{2}{*}{ 3. ICBE colleagues } & 0.3 & 0.3 & 0.8 & & & & & & & & & & & \\
\hline & 3 & 2 & 6 & & & & & & & & & & & \\
\hline \multirow[t]{2}{*}{ 4. ICBE supervisors } & 0.3 & 0.3 & 0.6 & 0.9 & & & & & & & & & & \\
\hline & 2 & 3 & 6 & 2 & & & & & & & & & & \\
\hline \multirow[t]{2}{*}{ 5. ICBE internal communications } & 0.2 & 0.4 & 0.5 & 0.4 & 0.8 & & & & & & & & & \\
\hline & 3 & 1 & 2 & 6 & 5 & & & & & & & & & \\
\hline \multirow[t]{2}{*}{ 6. ICBE external communications } & 0.2 & 0.6 & 0.3 & 0.3 & 0.5 & 0.8 & & & & & & & & \\
\hline & 4 & 1 & 0 & 2 & 7 & 9 & & & & & & & & \\
\hline \multirow[t]{2}{*}{ 7. ICBE friends \& family } & 0.2 & 0.4 & 0.4 & 0.4 & 0.6 & 0.5 & 0.9 & & & & & & & \\
\hline & 0 & 5 & 7 & 5 & 0 & 2 & 2 & & & & & & & \\
\hline \multirow[t]{2}{*}{ 8. Employment experience } & 0.2 & 0.5 & 0.5 & 0.5 & 0.6 & 0.5 & 0.6 & 0.7 & & & & & & \\
\hline & 5 & 0 & 6 & 9 & 8 & 6 & 0 & 6 & & & & & & \\
\hline \multirow[t]{2}{*}{ 9. Brand experience (sensory) } & 0.3 & 0.6 & 0.3 & 0.3 & 0.5 & 0.5 & 0.4 & 0.5 & 0.9 & & & & & \\
\hline & 2 & 0 & 9 & 5 & 1 & 4 & 6 & 4 & 3 & & & & & \\
\hline \multirow[t]{2}{*}{ 10. Brand experience (affective) } & 0.2 & 0.5 & 0.3 & 0.2 & 0.5 & 0.5 & 0.4 & 0.5 & 0.8 & 0.8 & & & & \\
\hline & 1 & 6 & 1 & 9 & 0 & 4 & 5 & 1 & 5 & 6 & & & & \\
\hline \multirow[t]{2}{*}{ 11. Brand experience (behavioural) } & 0.1 & 0.4 & 0.2 & 0.2 & 0.3 & 0.3 & 0.3 & 0.4 & 0.5 & 0.5 & 0.9 & & & \\
\hline & 9 & 5 & 6 & 9 & 2 & 5 & 4 & 1 & 4 & 4 & 1 & & & \\
\hline \multirow[t]{2}{*}{ 12. Brand experience (intellectual) } & 0.1 & 0.3 & 0.2 & 0.2 & 0.3 & 0.3 & 0.2 & 0.4 & 0.6 & 0.6 & 0.4 & 0.8 & & \\
\hline & 5 & 4 & 6 & 5 & 3 & 1 & 7 & 0 & 0 & 1 & 7 & 8 & & \\
\hline \multirow[t]{2}{*}{ 13. WOM } & 0.3 & 0.4 & 0.6 & 0.6 & 0.5 & 0.3 & 0.5 & 0.6 & 0.5 & 0.4 & 0.3 & 0.4 & 0.9 & \\
\hline & 9 & 4 & 2 & 2 & 3 & 8 & 4 & 7 & 8 & 7 & 4 & 4 & 3 & \\
\hline \multirow[t]{2}{*}{ 14. Attitudinal corporate brand pride } & 0.3 & 0.4 & 0.6 & 0.6 & 0.5 & 0.3 & 0.5 & 0.6 & 0.5 & 0.4 & 0.3 & 0.4 & 0.8 & 0.9 \\
\hline & 8 & 4 & 2 & 1 & 3 & 8 & 2 & 9 & 7 & 3 & 5 & 1 & 3 & 0 \\
\hline
\end{tabular}

$\overline{\text { Note } .}$ DCBE $=$ direct product-related corporate brand experience, $\mathrm{ICBE}=$ indirect product-related corporate brand experience, WOM $=$ word of mouth.

Table 4. Correlations and quality criteria measurement models of study 2 .

\begin{tabular}{|c|c|c|c|c|c|c|c|c|c|c|c|c|c|c|c|}
\hline Construct & $\mathrm{CR}$ & $\alpha$ & 1 & 2 & 3 & 4 & 5 & 6 & 7 & 8 & 9 & 10 & 11 & 12 & 13 \\
\hline 1. DCBE & $\mathrm{n} / \mathrm{a}$ & $\mathrm{n} / \mathrm{a}$ & 1 & & & & & & & & & & & & \\
\hline $\begin{array}{l}\text { 2. } \quad \text { DCBE } \\
\text { organisational }\end{array}$ & 0.93 & 0.91 & 0.87 & 0.73 & & & & & & & & & & & \\
\hline $\begin{array}{l}\text { 3. DCBE } \\
\text { private }\end{array}$ & 0.97 & 0.96 & 0.81 & 0.43 & 0.86 & & & & & & & & & & \\
\hline 4. non-PCBE & $\mathrm{n} / \mathrm{a}$ & $\mathrm{n} / \mathrm{a}$ & 0.43 & 0.33 & 0.37 & 1 & & & & & & & & & \\
\hline $\begin{array}{l}\text { 5. ICBE } \\
\text { colleagues }\end{array}$ & 0.96 & 0.95 & 0.29 & 0.24 & 0.22 & 0.87 & 0.86 & & & & & & & & \\
\hline ICBE & 0.96 & 0.95 & 0.30 & 0.25 & 0.24 & 0.78 & 0.72 & 0.87 & & & & & & & \\
\hline
\end{tabular}




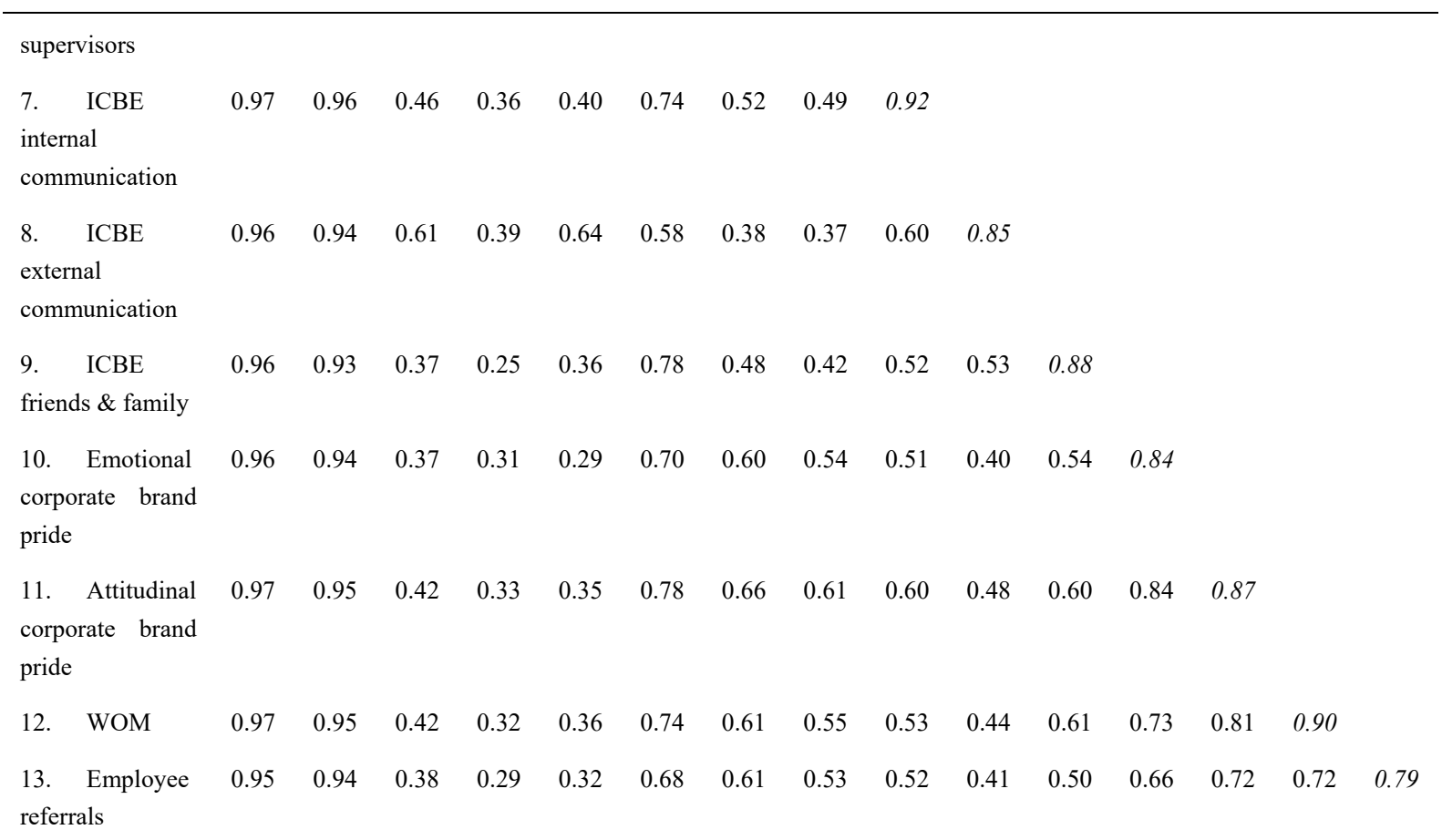

Notes. Average variance extracted (AVE) appears on the diagonal in italics, DCBE = direct product-related corporate brand experience, ICBE $=$ indirect product-related corporate brand experience, $\mathrm{WOM}=$ word of mouth, $\mathrm{CR}=$ composite reliability, $\alpha=$ Cronbach's $\alpha, \mathrm{n} / \mathrm{a}=$ not applicable (because it uses a formative indicator specification).

Table 5. Mediation analysis results of study 2

\begin{tabular}{lllll}
\hline Relationship & Direct Effect $(t$-value $)$ & $\begin{array}{l}\text { Indirect Effect } \\
(t \text {-value })\end{array}$ & Interpretation & Conclusion \\
\hline DCBE $\rightarrow$ Attitudinal corporate brand pride & $\begin{array}{lll}0.02^{\text {n.s. }} \\
(0.72)\end{array}$ & $\begin{array}{l}0.02^{\text {n.s. }} \\
(0.59)\end{array}$ & $\begin{array}{l}\text { No mediation } \\
\text { No effect }\end{array}$ & H1a not supported \\
ICBE $\rightarrow$ Attitudinal corporate brand pride & $0.37^{* * *}$ & $\begin{array}{l}0.39^{* * *} \\
(7.16)\end{array}$ & Complementary partial mediation & H1b supported \\
\hline
\end{tabular}

Notes. Significant at: $* * * \mathrm{p}<0.001 ; \mathrm{DCBE}=$ direct product-related corporate brand experience, $\mathrm{ICBE}=$ indirect product-related corporate brand experience, n.s.: not significant.

Table 6. Direct relationship results of study 2

\begin{tabular}{|c|c|c|c|}
\hline Hypothesis & Path & Standardised Coefficient & Conclusion \\
\hline & DCBE $\rightarrow$ Emotional corporate brand pride & $0.03^{\text {n.s. }}$ & \\
\hline & ICBE $\rightarrow$ Emotional corporate brand pride & $0.67^{* * *}$ & \\
\hline & Emotional corporate brand pride & $0.84^{* * *}$ & \\
\hline & $\rightarrow$ Attitudinal corporate brand pride & & \\
\hline $2 \mathrm{a}$ & Attitudinal corporate brand pride $\rightarrow$ WOM & $0.81^{* * * *}$ & Supported \\
\hline \multirow[t]{2}{*}{$2 b$} & Attitudinal corporate brand pride & $0.72^{* * * *}$ & Supported \\
\hline & $\rightarrow$ Employee referrals & & \\
\hline
\end{tabular}

Notes. Significant at: $* * * \mathrm{p}<0.001 ; \mathrm{DCBE}=$ direct product-related corporate brand experience, $\mathrm{ICBE}=$ indirect product-related corporate brand experience, $\mathrm{WOM}=$ word of mouth, n.s.: not significant. 
Table 7. Results of the Heterotrait-Monotrait ratio analysis of STF study 2

\begin{tabular}{|c|c|c|c|c|c|c|c|c|c|c|c|}
\hline HTMT & 1 & 2 & 3 & 4 & 5 & 6 & 7 & 8 & 9 & 10 & 11 \\
\hline \multicolumn{12}{|l|}{ 1. DCBE organisational } \\
\hline 2. DCBE private & 0.46 & & & & & & & & & & \\
\hline 3 ICBE colleagues & 0.25 & 0.23 & & & & & & & & & \\
\hline 4 ICBE supervisors & 0.27 & 0.25 & 0.76 & & & & & & & & \\
\hline $5 \mathrm{ICBE}$ internal communications & 0.38 & 0.42 & 0.55 & 0.52 & & & & & & & \\
\hline 6 ICBE external communications & 0.42 & 0.68 & 0.39 & 0.39 & 0.62 & & & & & & \\
\hline 7 ICBE friends \& family & 0.27 & 0.39 & 0.51 & 0.44 & 0.56 & 0.56 & & & & & \\
\hline 8 Emotional corporate brand pride & 0.33 & 0.30 & 0.64 & 0.57 & 0.54 & 0.42 & 0.58 & & & & \\
\hline 9 Attitudinal pride & 0.35 & 0.37 & 0.69 & 0.65 & 0.63 & 0.49 & 0.63 & 0.89 & & & \\
\hline $10 \mathrm{WOM}$ & 0.35 & 0.38 & 0.64 & 0.58 & 0.55 & 0.46 & 0.65 & 0.77 & 0.86 & & \\
\hline 11 Employee referrals & 0.31 & 0.34 & 0.64 & 0.55 & 0.54 & 0.43 & 0.53 & 0.69 & 0.75 & 0.75 & \\
\hline
\end{tabular}

Notes. Bold $=$ HTMT $>0.85, \mathrm{DCBE}=$ direct product-related corporate brand experience, $\mathrm{ICBE}=$ indirect product-related corporate brand experience, $\mathrm{WOM}=$ word of mouth; HTMT = heterotrait-monotrait ratio.

Nomological validity was also evaluated. Since corporate brand experience, whether direct or indirect, is usually positive, it was expected that each dimension would positively relate to constructs measuring forms of (employee) satisfaction or loyalty. Prior studies have reported significant relationships between forms of (brand) experience and satisfaction or loyalty perceptions (Brakus et al., 2009; Klein et al., 2016). Therefore, each dimension of the (new) corporate brand experience scale should relate positively to (attitudinal) corporate brand pride and word of mouth (WOM) for the scale to possess nomological validity (Turhan, 2014). The results showed that the dimensions of corporate brand experience were significant predictors of corporate brand pride and WOM (see Tab. 2). In addition, the $r^{2}$ values of (attitudinal) corporate brand pride and WOM (dependent variables) were analysed. Here, ICBE showed the highest $r^{2}$ value regarding brand pride $\left(r^{2}=0.45\right)$ and WOM $\left(r^{2}=0.47\right)$ compared with the constructs of Brakus et al. (2009) $\left(r^{2}=0.26\right.$ brand pride; $r^{2}=0.28$ WOM) or Edwards and Edwards (2013) $\left(r^{2}\right.$ $=0.38$ brand pride; $r^{2}=0.36 \mathrm{WOM}$ ). Based on the results, the ICBE scale showed adequate nomological validity.

3. Study 2: Impact of Corporate Brand Experience on Employees'Corporate Brand Pride and BrandSupporting Behaviours

\subsection{Integrating employee corporate brand pride and brand commitment into internal branding research}

In line with AET, the marketing literature suggests that experiences evoke emotions (Brakus et al., 2009; Iglesias et al., 2011). One emotion that has received an increasing amount of attention in organisational research is the employee's pride (Gouthier \& Rhein, 2011; Brosi, Spörrle, \& Welpe, 2018; Lythreatis, Mostafa, \& Wang, 2019; Ritzenhöfer, Brosi, Spörrle, \& Welpe, 2019; Kraemer et al., 2020). Thus, the aim of the second study was investigating whether employee corporate brand experience results in the emotion of pride in employees. Pride is among the most important employee emotions (e.g. Verbeke, 2004), and it represents a valuable attitude in the organisational context (Lea \& Webley, 1997), fostering positive employee behaviour. In study 2 it is assumed that pride is also important for the corporate brand as it strongly motivates employee behaviour, with an emphasis on brand citizenship behaviour (Helm et al., 2016). Among the diverse classifications of pride in literature, the focus is within the emotional and attitudinal corporate brand pride.

Emotional pride in organisational research is defined as a short-lived, discreet, and intensely felt self-conscious emotion (Verbeke, 2004), typically triggered by a specific event. Employees can feel emotional pride due to an event (e.g. when a new product is launched and presented to the employees or winning a design or best employee award) (Gouthier \& Rhein, 2011). In addition, employees can be proud of their colleagues' achievements (e.g. winning an important new customer) (Gouthier \& Rhein, 2011). Helm et al. (2016, p. 62) state that emotional 
corporate brand pride arises 'when brand attributes exceed expectations in comparison with competitor brands or past brand performance'. Therefore, this paper suggests that emotional corporate brand pride can result from a successful achievement for a corporate brand.

Pride can also be an attitude. Here, pride does not stem from the evaluation of specific corporate achievements but rather from general organisational successes, such as being associated with a prestigious corporate brand (e.g. Google, Apple or Porsche) (Gouthier \& Rhein, 2011; Helm et al., 2016). Attitudinal corporate brand pride is a consequence of repeatedly felt emotional corporate brand pride; it is more stable, and thus, more suitable for predicting employee behaviours (Gouthier \& Rhein, 2011). Emotions are closely linked to attitudes, which sometimes leads to both being equated in organisational research (Weiss, 2002), making it necessary to delineate the terms of emotional and attitudinal corporate brand pride. Attitudes are overall evaluations, characterised not only by a set of feelings and emotions towards an attitude object but also the underlying affective experiences (i.e. emotions) (Breckler \& Wiggins, 1989). In contrast, emotions result from single events, and for repeatedly felt emotions, cause attitudes (Gouthier \& Rhein, 2011). In sum, 'since emotions have downstream consequences for attitudes and behaviours, attitudes are post-emotional responses' (Gouthier \& Rhein, 2011, p. 636).

\subsection{Affective Events Theory as a Theoretical Framework for Developing Hypotheses}

AET is used to explain the interplay of experiences, emotions, attitudes and behaviours (Weiss \& Cropanzano, 1996). The theory 'explains the structure, causes and consequences of employees' affective experiences at work' (Matta, Erol-Korkmaz, Johnson, \& Bicaksiz, 2014, p. 922). Work events, such as corporate brand experiences, are proximal causes of these affective reactions (i.e. emotional corporate brand pride) (Herrbach \& Mignonac, 2004); these, in turn, influence work-related attitudes (i.e. attitudinal corporate brand pride) and behaviours (i.e. brandsupporting behavior) (Weiss \& Cropanzano, 1996). Following Weiss and Cropanzano (1996), in this paper a work event is defined as an event that occurs in a work-related setting during a certain period; it can be either direct or indirect.

As an emotion, pride is said to be caused by a specific stimulus or event (e.g. Decrop \& Derbaix, 2010). Arnett, Laverie and Mclane (2002, p. 90) state that 'pride in an organisation results from specific perceptions of the organisation and from experiences with that organisation'. Since marketing research has found that emotions result from brand experience (e.g. Brakus et al., 2009), it is postulated that a brand-based experience could be a workrelated event. Similarly, in a consumer-brand context, Decrop and Derbaix (2010, p. 588) state that 'pride is presented as an emotion arising from a range of buying and consumption situations'. Since consumers and employees are both stakeholders of a corporate brand - where employees are not only employed at a corporation but are often also its consumers - the results indicate that the more employees experience the corporate brand, the more they will feel the emotion of pride. Furthermore, 'attitudes typically result from experiences; they are learnable' (Gouthier \& Rhein, 2011, p. 636). By definition, emotions and attitudes are interrelated, and attitudinal corporate brand pride could emerge from repeatedly felt emotional corporate brand pride. This assumption is in line with AET, as well as several studies showing that affective experiences at work lead to attitudes (Weiss \& Cropanzano, 1996). Consequently, in an employee brand context, emotions have downstream consequences for attitudes and behaviours, and attitudinal corporate brand pride stems from the repeatedly felt emotional pride for one's corporation. In this vein, the following hypothesis has been developed:

\section{H1: Emotional corporate brand pride mediates the positive effects of (a) DCBEs and (b) ICBEs on attitudinal corporate brand pride.}

To provide a full model, including outcomes of brand pride, frequently investigated positive employee behaviours, such as WOM and employee referrals were used. According to AET, attitudes influence cognitively driven behaviours. Therefore, in an internal branding context, corporate brand pride and commitment positively influence the employees' brand-supporting behaviours, which contribute to the company's branding efforts (Löhndorf \& Diamantopoulos, 2014). In addition, since a few of these relationships have already been shown (i.e. the relationships between attitudinal corporate brand pride and brand commitment and brand commitment and WOM/employee referrals), we did not establish hypotheses for them (marked in Figure 3 with dotted lines).

According to Arnett et al. (2002), pride can be seen as a motivator for positive employee behaviours. Therefore:

H2: Attitudinal corporate brand pride positively influences (a) employees' WOM and (b) employee referrals.

However, to test the effects of brand pride over and above brand commitment, and since brand pride positively affects brand commitment, it was included in this research. 


\subsection{Method}

\subsubsection{Participants}

Data was obtained through a large-scale online survey of companies operating in Germany, which resulted in a dataset with 370 completed surveys. The dataset was checked for careless responses (Nysveen \& Pedersen, 2015) and deleted missing values (Roth, Schwitzer, \& Switzer, 1999). To identify data with careless responses, half the average processing time (median), which was 14 min and 5 seconds, was used as the minimal response time. As such, a processing time shorter than 7 minutes and 3 seconds indicated that there was only a superficial reading by the respondent, with no study of the questions. Next missing values were checked and as Roth et al. (1999) suggest, those sets in which more than $30 \%$ of the data were missing were deleted; this resulted in a usable sample of 282 observations. In total, $128(45.4 \%)$ of the employees who participated were female and 152 were male (53\%). Two participants did not indicate their sex $(0.70 \%)$. Most of the participants were employees $(197 ; 69.9 \%)$, and 57 $(20.2 \%)$ were leaders. In addition, most of the participants worked for companies with more than 500 employees $(234 ; 83 \%)$ and had a bachelor's degree as the lowest education level $(208,72.7 \%)$.

\subsubsection{Measures}

Whenever possible, existing and validated scales to measure the conceptually defined constructs were used such as for corporate brand experience. Emotional corporate brand pride was measured with a five-item scale adapted from Gouthier and Rhein (2011). To assess the level of attitudinal corporate brand pride, the scale was adapted and used a three-item scale, also by Gouthier and Rhein (2011), adding one item to the existing scale to ensure reliability ('I'm proud to be part of [corporate brand name]'). For measuring brand-supporting employee behaviours, WOM, consisting of three items adapted from Morhart et al. (2009), and employee referrals was used, which was measured with five items by drawing on Bloemer (2010). Tables gives an overview of the final item set used in this study.

\section{Measures Table 1}

\begin{tabular}{|c|c|c|c|}
\hline Constructs & $\begin{array}{l}\text { Items } \\
\text { Inspired } \\
\text { by }\end{array}$ & $\begin{array}{l}\text { Factor } \\
\text { Loadings } \\
\text { Study } 1\end{array}$ & $\begin{array}{l}\text { Factor } \\
\text { Loadings } \\
\text { Study } 2\end{array}$ \\
\hline \multicolumn{4}{|l|}{ DCBE organisational } \\
\hline I experience products of [corporate brand name] in a vocational setting. & & 0.89 & 0.87 \\
\hline $\begin{array}{l}\text { I come in contact with products of [corporate brand name] in an occupational } \\
\text { context. }\end{array}$ & & 0.91 & 0.87 \\
\hline $\begin{array}{l}\text { I experience products of [corporate brand name] in a professional context with } \\
\text { my senses (i.e. hearing, sight, touch, etc.). }\end{array}$ & & 0.80 & 0.87 \\
\hline $\begin{array}{l}\text { There are many opportunities at [corporate brand name] to experience products, } \\
\text { and I use them often. }\end{array}$ & & 0.70 & 0.86 \\
\hline I use existing offers to experience products in the context of work. & & 0.66 & 0.81 \\
\hline \multicolumn{4}{|l|}{ DCBE private } \\
\hline I often perceive products of our corporate brand in a private context. & & 0.89 & 0.91 \\
\hline I experience products of [corporate brand name] in a private context. & & 0.94 & 0.95 \\
\hline I come in contact with products of [corporate brand name] in a private setting. & & 0.95 & 0.94 \\
\hline $\begin{array}{l}\text { I experience products of [corporate brand name] in a private surrounding with } \\
\text { my senses (i.e. hearing, sight, touch, etc.). }\end{array}$ & & 0.95 & 0.94 \\
\hline $\begin{array}{l}\text { I use the possibility to experience products of [corporate brand name] in a private } \\
\text { context. }\end{array}$ & & 0.93 & 0.91 \\
\hline \multicolumn{4}{|l|}{ ICBE colleagues } \\
\hline I experience the values [corporate brand name] stands for through my colleagues. & & 0.91 & 0.94 \\
\hline I experience the values of [corporate brand name] by dealing with my colleagues. & & 0.91 & 0.94 \\
\hline $\begin{array}{l}\text { My colleagues compellingly exemplify the values of [corporate brand name] } \\
\text { inside and outside the organisation and act as role models. }\end{array}$ & & 0.83 & 0.92 \\
\hline $\begin{array}{l}\text { In conversations with my colleagues, I experience the values [corporate brand } \\
\text { name] stands for. }\end{array}$ & & 0.78 & 0.91 \\
\hline
\end{tabular}


Measures Table 2

\begin{tabular}{|c|c|c|c|}
\hline Constructs & $\begin{array}{l}\text { Items } \\
\text { Inspired } \\
\text { by }\end{array}$ & $\begin{array}{l}\text { Factor } \\
\text { Loadings } \\
\text { Study } 1\end{array}$ & $\begin{array}{l}\text { Factor } \\
\text { Loadings } \\
\text { Study } 2\end{array}$ \\
\hline \multicolumn{4}{|l|}{ ICBE supervisors } \\
\hline $\begin{array}{l}\text { I experience the values [corporate brand name] stands for through my supervisor (i.e. in } \\
\text { conversations, etc.). }\end{array}$ & & 0.92 & 0.92 \\
\hline I experience the values of [corporate brand name] by dealing with senior management. & & 0.96 & 0.95 \\
\hline $\begin{array}{l}\text { Senior management compellingly exemplifies the values of the company inside and outside } \\
\text { the organisation and act as a role model. }\end{array}$ & & 0.90 & 0.93 \\
\hline $\begin{array}{l}\text { In meetings with senior management, I experience the values [corporate brand name] stands } \\
\text { for. }\end{array}$ & & 0.91 & 0.93 \\
\hline \multicolumn{4}{|l|}{ ICBE internal communications } \\
\hline $\begin{array}{l}\text { There are stories and anecdotes circulating around the company that support what our } \\
\text { corporate brand stands for. }\end{array}$ & & 0.68 & eliminated \\
\hline $\begin{array}{l}\text { Through information in our internal communications, I experience what our corporate brand } \\
\text { stands for. }\end{array}$ & & 0.90 & 0.95 \\
\hline I experience the corporate brand through editorial content in our internal communications. & & 0.95 & 0.97 \\
\hline $\begin{array}{l}\text { I come in contact with the corporate brand through available media in our internal } \\
\text { communications. } \\
\text { ICBE external communications }\end{array}$ & & 0.87 & 0.96 \\
\hline $\begin{array}{l}\text { Through information on the Internet (i.e. blogs, video, pictures, etc.), I experience what our } \\
\text { corporate brand stands for. }\end{array}$ & & 0.75 & 0.87 \\
\hline $\begin{array}{l}\text { I experience the corporate brand through editorial content in external communications (i.e. } \\
\text { television, radio, etc.). }\end{array}$ & & 0.87 & 0.92 \\
\hline $\begin{array}{l}\text { I experience our corporate brand in a private setting through external communication } \\
\text { activities. }\end{array}$ & & 0.97 & 0.96 \\
\hline $\begin{array}{l}\text { I come in contact with the corporate brand in a private context through the actions of external } \\
\text { communication. }\end{array}$ & & 0.97 & 0.96 \\
\hline
\end{tabular}

Measures Table 3

\begin{tabular}{|c|c|c|c|}
\hline Constructs & $\begin{array}{l}\text { Items } \\
\text { Inspired } \\
\text { by }\end{array}$ & $\begin{array}{l}\text { Factor } \\
\text { Loadings } \\
\text { Study } 1\end{array}$ & $\begin{array}{l}\text { Factor } \\
\text { Loadings } \\
\text { Study } 2\end{array}$ \\
\hline \multicolumn{4}{|l|}{ ICBE friends \& family } \\
\hline In my private surroundings, [corporate brand name] is often talked about in a positive way. & & 0.99 & 0.96 \\
\hline $\begin{array}{l}\text { I often notice that people in my private surroundings speak positively about [corporate brand } \\
\text { name]. }\end{array}$ & & 0.96 & 0.96 \\
\hline I often perceive that [corporate brand name] has a good reputation. & & 0.82 & 0.89 \\
\hline $\begin{array}{l}\text { Employment experience } \\
\text { [Corporate brand name] offers me an employment experience that would be difficult to get } \\
\text { elsewhere. }\end{array}$ & $\begin{array}{l}\text { Edwards } \\
\text { and } \\
\text { Edwards }\end{array}$ & eliminated & $\mathrm{n} / \mathrm{a}$ \\
\hline $\begin{array}{l}\text { As an employer, [corporate brand name] offers terms and conditions that would be difficult to } \\
\text { find elsewhere. }\end{array}$ & (2013) & 0.75 & $\mathrm{n} / \mathrm{a}$ \\
\hline $\begin{array}{l}\text { As an employer, [corporate brand name] provides me with a compensation package that would } \\
\text { be difficult to find elsewhere. }\end{array}$ & & 0.72 & $\mathrm{n} / \mathrm{a}$ \\
\hline $\begin{array}{l}\text { As an employer, [corporate brand name] provides me with the autonomy that it would be } \\
\text { difficult to find elsewhere. }\end{array}$ & & eliminated & $\mathrm{n} / \mathrm{a}$ \\
\hline $\begin{array}{l}\text { As an employer, [corporate brand name] is more supportive of employees than you would } \\
\text { expect to find elsewhere. }\end{array}$ & & 0.82 & $\mathrm{n} / \mathrm{a}$ \\
\hline $\begin{array}{l}\text { As an employer, [corporate brand name] provides me with developmental opportunities that } \\
\text { would be difficult to find elsewhere. }\end{array}$ & & 0.74 & $\mathrm{n} / \mathrm{a}$ \\
\hline
\end{tabular}


Measures Table 4

\begin{tabular}{|c|c|c|c|}
\hline Constructs & $\begin{array}{l}\text { Items } \\
\text { Inspired } \\
\text { by }\end{array}$ & $\begin{array}{l}\text { Factor } \\
\text { Loadings } \\
\text { Study } 1 \\
\end{array}$ & $\begin{array}{l}\text { Factor } \\
\text { Loadings } \\
\text { Study } 2 \\
\end{array}$ \\
\hline Brand experience (sensory) & Brakus & & \\
\hline This brand makes a strong impression on my visual sense or other senses. & et al, & 0.94 & $\mathrm{n} / \mathrm{a}$ \\
\hline I find this brand interesting in a sensory way. & $(2009)$ & 0.94 & $\mathrm{n} / \mathrm{a}$ \\
\hline This brand does not appeal to my senses (R). & & 0.91 & $\mathrm{n} / \mathrm{a}$ \\
\hline Brand experience (affective) & Brakus & & \\
\hline This brand induces feelings and sentiments. & et $a l$, & 0.89 & $\mathrm{n} / \mathrm{a}$ \\
\hline I do not have strong emotions for this brand (R). & $(2009)$ & 0.82 & $\mathrm{n} / \mathrm{a}$ \\
\hline This brand is an emotional brand. & & 0.86 & $\mathrm{n} / \mathrm{a}$ \\
\hline Brand experience (behavioural) & Brakus & & \\
\hline I engage in physical actions and behaviours when I use this brand. & et $\quad a l$, & 0.91 & $\mathrm{n} / \mathrm{a}$ \\
\hline This brand results in bodily experiences. & (2009) & 0.97 & $\mathrm{n} / \mathrm{a}$ \\
\hline This brand is not action oriented (R). & & 0.85 & $\mathrm{n} / \mathrm{a}$ \\
\hline Brand experience (intellectual) & Brakus & & \\
\hline I engage in a lot of thinking when I encounter this brand. & et al, & 0.95 & $\mathrm{n} / \mathrm{a}$ \\
\hline This brand does not make me think $(\mathrm{R})$. & $(2009)$ & 0.95 & $\mathrm{n} / \mathrm{a}$ \\
\hline This brand stimulates my curiosity and problem solving. & & 0.73 & $\mathrm{n} / \mathrm{a}$ \\
\hline
\end{tabular}

Measures Table 5

\begin{tabular}{|c|c|c|c|}
\hline Constructs & $\begin{array}{l}\text { Items } \\
\text { Inspired } \\
\text { by }\end{array}$ & $\begin{array}{l}\text { Factor } \\
\text { Loadings } \\
\text { Study } 1\end{array}$ & $\begin{array}{l}\text { Factor } \\
\text { Loadings } \\
\text { Study } 2\end{array}$ \\
\hline Emotional corporate brand pride & \multirow{6}{*}{$\begin{array}{l}\text { Gouthier } \\
\text { and } \\
\text { Rhein } \\
(2011)\end{array}$} & \multirow[b]{3}{*}{$\mathrm{n} / \mathrm{a}$} & \\
\hline $\begin{array}{l}\text { Please remember an event in which [corporate brand name] was most recently successful. Please } \\
\text { evaluate what you are feeling in such moments. }\end{array}$ & & & \\
\hline In these moments, I am happy to be a member of [corporate brand name]. & & & 0.95 \\
\hline In these moments, I have a feeling of joy to be a part of [corporate brand name]. & & $\mathrm{n} / \mathrm{a}$ & 0.94 \\
\hline In these moments, I am proud of what [corporate brand name] has achieved. & & $\mathrm{n} / \mathrm{a}$ & 0.94 \\
\hline In these moments, I have the feeling that [corporate brand name] is doing something meaningful. & & $\mathrm{n} / \mathrm{a}$ & 0.84 \\
\hline Attitudinal corporate brand pride & \multicolumn{2}{|c|}{ Gouthier } & \\
\hline I feel proud to work for [corporate brand name]. & and & 0.94 & 0.95 \\
\hline I feel proud to contribute to [corporate brand name]'s success. & Rhein & 0.88 & 0.89 \\
\hline I feel proud to tell others I am working for [corporate brand name]. & $(2011)$ & 0.87 & 0.93 \\
\hline I feel proud to be a part of [corporate brand name]. & $\begin{array}{l}\text { (add. } \\
\text { Item) }\end{array}$ & 0.93 & 0.97 \\
\hline WOM & \multicolumn{2}{|l|}{ Morhart } & \\
\hline I talk up [corporate brand name] to people I know. & \multirow{3}{*}{$\begin{array}{l}\text { et } a l \text {, } \\
(2009)\end{array}$} & 0.93 & 0.95 \\
\hline I bring up [corporate brand name] in a positive way in conversations I have with friends and acquaintanc & & 0.96 & 0.96 \\
\hline In social situations, I often speak favourably about [corporate brand name]. & & 0.91 & 0.94 \\
\hline
\end{tabular}

Measures Table 6

\begin{tabular}{|c|c|c|c|c|}
\hline Items & Constructs & $\begin{array}{l}\text { Items } \\
\text { Inspired } \\
\text { by }\end{array}$ & $\begin{array}{l}\text { Factor } \\
\text { Loadings } \\
\text { Study } 1\end{array}$ & $\begin{array}{l}\text { Factor } \\
\text { Loadings } \\
\text { Study } 2\end{array}$ \\
\hline \multicolumn{5}{|c|}{ Employee referrals } \\
\hline I recon & who seeks employment advice. & \multirow{4}{*}{$\begin{array}{l}\text { Bloemer } \\
(2010)\end{array}$} & $\mathrm{n} / \mathrm{a}$ & 0.89 \\
\hline I encou & hy organisation. & & $\mathrm{n} / \mathrm{a}$ & 0.93 \\
\hline I appro & that my employer offers an interesting job, which suits them. & & $\mathrm{n} / \mathrm{a}$ & 0.88 \\
\hline I forwa & seeking employment. & & $\mathrm{n} / \mathrm{a}$ & 0.86 \\
\hline
\end{tabular}




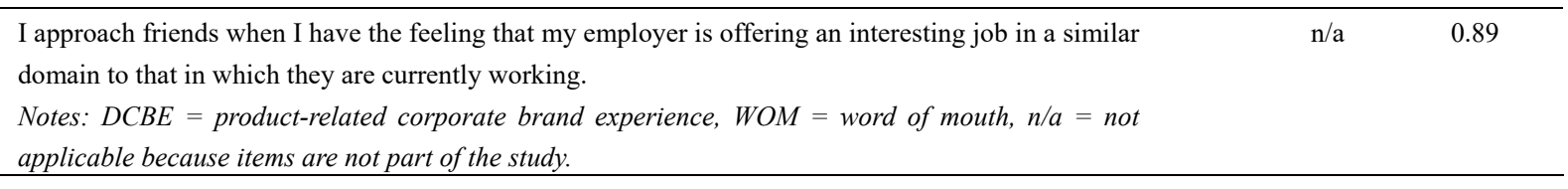

\subsubsection{Methodological Procedures}

Structural equation modelling was applied using the PLS procedure (Lohmöller, 1989) to test the hypotheses. PLS has several benefits, making it a valuable tool in this second study (Hair, Hult, Ringle, \& Sarstedt, 2013). First, it functions with complex models, especially if these contain higher order variables and formative measures (Hair, Sarstedt, Ringle, \& Mena, 2012), making it possible to evaluate the independent variables_-DCBE and ICBEwhich are type-II, second-order constructs consisting of reflective first-order and formative second-order indicators that cannot be estimated through covariance-based structural equation modelling (Jarvis, MacKenzie, \& Podsakoff, 2003). Second, PLS is especially useful when the model contains mode b composites (Hair et al., 2012). For estimating the paths, SmartPLS3.0 (Henseler, Ringle, \& Sarstedt, 2015) was used, while bootstrap resampling (5000 replications) helped assess the estimates' stability (Chin, Marcolin, \& Newsted, 2003). Moreover, the guidelines provided by Becker et al. (2012) for developing higher order constructs were followed, specifically, for specifying formative hierarchical construct models by an indicator replication approach using mode $b$.

Since employees' individual perceptions and attitudes is in the interest of study 2, self-reported data for all the variables were used. Self-reported surveys are one of the most frequently used forms of collecting empirical data, leading to a 'great deal of debate, but limited consensus, on the extent of common method variance (CMV) associated with them' (Nedkovski, Guerci, Battisti, \& Siletti, 2017, p. 22). Therefore, several precautions for detecting, minimising and estimating the effects of CMV were taken. In line with prior research (Podsakoff, MacKenzie, Lee, \& Podsakoff, 2003) and state-of-the-art directions, different procedural remedies were used and tested statistically for determining whether CMV affected the data. In addition, for minimising the social desirability bias, the participants were guaranteed full anonymity, and only the required personal data were collected, which was also explained and done at the end of the questionnaire. Furthermore, the question order was counterbalanced to disrupt the logical flow. Harman's one-factor test was applied to all latent variables, and no single factor explained a substantial amount of covariance. Due to the limitations of Harman's one-factor test, Lindell and Whitney (2001) approach was also used. The 'organisational performance demands' were used as a marker variable according to the study of Homburg and Pflesser (2000). Finally, based on all the correlations, which remained significant after controlling for the marker variable effect, CMV was unlikely to affect the conclusions.

\section{Analysis and Results}

\subsection{The Measurement Model and Structural Model Fit}

All the latent variables, including the type-II second-order constructs featuring a reflective first-order measurement, used reflective measurement models. According to Chin (2010), factor loadings and CR should exceed a cut-off criterion of 0.7 , and the AVE should be above 0.5 , while the highest squared correlation with any other construct should be lower than the AVE (Fornell/Larcker criterion). Furthermore, Cronbach's $\alpha$ values should exceed 0.7 (Nunnally, 1978), and the Stone-Geisser $Q^{2}$ communality should be above 0 (Fornell \& Cha, 1994) for assessing predictive validity. Overall, after eliminating one item due to a factor loading below 0.7 (Appendix 2), all the data fitted the abovementioned criteria, with the smallest $Q^{2}$ value in the data at 0.40 . In addition to the Fornell/Larcker criterion (Fornell \& Larcker, 1981), we checked the heterotrait-monotrait (HTMT) criterion for discriminant validity, representing a useful measure for first-order composites. The robust cut-off value was found at 0.85 and the maximum HTMT value at 0.90 (Henseler, Ringle, \& Sarstedt, 2015). Only two relationships exceeded the HTMT value at 0.85 but remained below 0.90 (see Tab. 7), namely, the relationships between emotional and attitudinal corporate brand pride $(\mathrm{HTMT}=0.89)$ and between attitudinal corporate brand pride and WOM $($ HTMT $=0.86$ ). Since emotional corporate brand pride and attitudinal corporate brand pride are relatively closely related constructs, both procedures - the Fornell/Larker and HTMT value - were used for assessing discriminant validity; according to both tests, this was found to be positive.

All the reflective measurement models were tested using AMOS 23. All the criteria for convergent validityCronbach's $\alpha$, CR and AVE values - exceeded the common thresholds (as stated above). Together, since all criteria fitted the thresholds, the validity and reliability — especially discriminant validity — were assumed for all reflective measures. 
As type-II second-order constructs have formative second-order measurement models, formative quality criteria were used for assessing their validity and reliability. In this regard, the factor weights require significance and must exceed 0.1 (Lohmöller, 1989). In addition, the latent variable correlations - for assessing discriminant validity - should be below 0.9 , and the variance inflation factor (VIF) values should be below 5 to represent strong quality criteria (Hair et al., 2013). The highest VIF value was found at 2.34. Therefore, the formative variable criteria were met (see also Tab. 4).

For assessing structural model fit, $r^{2}$ values should exceed 0.33 for endogenous latent variables (Chin, 1998). This is given for all variables (see Fig 3). Furthermore, for assessing multicollinearity, VIF and the Stone-Geisser $Q^{2}$ for reductive validity were analysed. All the values for VIF were below 2.4, indicating no multicollinearity. In addition, all the values for $Q^{2}$ exceeded 0 , ensuring predictive relevance.

\subsection{Results of Direct and Mediating Effects}

The analysis revealed that most of the hypotheses (i.e. $H 1 b, H 2 a$ and $H 2 b$ ) could be confirmed, and only one hypothesis $(H 1 a)$ needed to be rejected.

For performing mediation analysis, the procedure provided by Zhao, Lynch and Chen (2010) was followed, which Hair et al. (2017) also suggest to use for mediator analysis in PLS structural equation modeling. First, the indirect effect must be checked for significance (see $T a b$. 5). If the indirect effect is not significant-which is the case for the indirect effect from DCBE on attitudinal corporate brand pride - the direct effect needs to be checked (see Tab. 6). If the direct effect is not significant either, no effect (including mediation) does exist. This is the case for the effect of DCBE on attitudinal corporate brand pride, hence $H \mathrm{la}$ needs to be rejected. However, the direct effect of ICBE on attitudinal corporate brand pride as well as the indirect effect (via emotional corporate brand pride) is significant, so that partial mediation exists. According to Zhao et al. (2010) it is to be classified as complementary partial mediation since both effects exhibit the same direction.

In accordance with $H 2 a$ and $H 2 b$, corporate brand pride was found to trigger the brand-supporting behaviours WOM $(\beta=0.81, \mathrm{p}<0.001)$ and employee referrals $(\beta=0.72, \mathrm{p}<0.001)$. The results are shown in Tab. 5, Tab. 6 and Fig. 3.

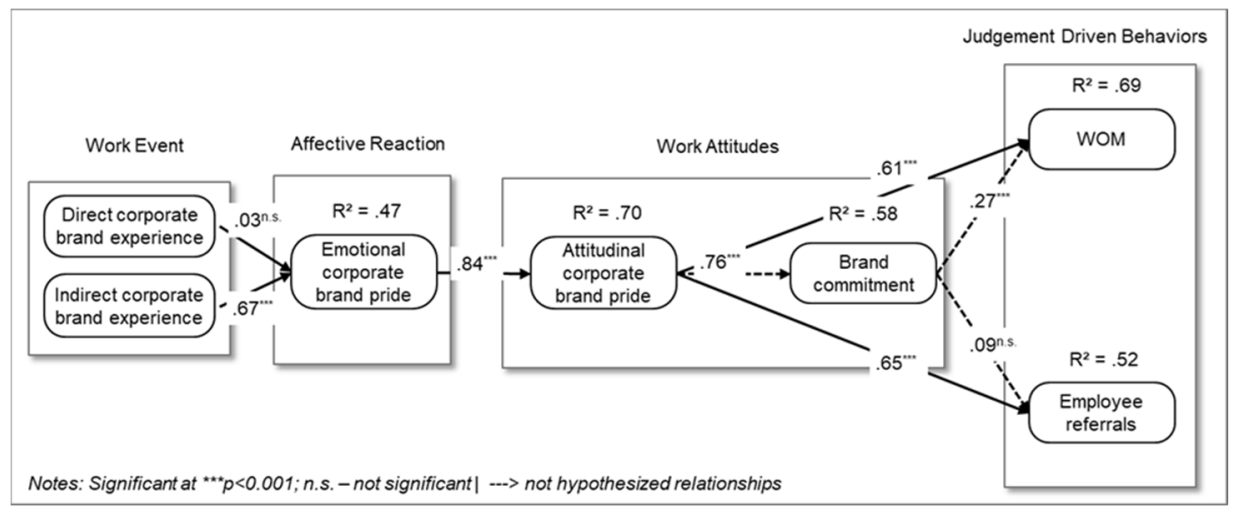

Figure 3. Structural model for study 2

\section{Discussion and Further Research}

In line with AET, this research shows that ICBE through work-related events leads to brand-related emotions, such as corporate brand pride. The results show that emotions should be considered, when theorizing about brands. However, this paper stated that ICBE and DCBE trigger emotions, such as corporate brand pride, which could only be confirmed for ICBE. Based on these findings, habituation was tested to determine whether it could provide a possible explanation for the lack of effect regarding DCBE on brand pride. In addition, it is estimated whether the relationship between corporate brand experiences and emotional corporate brand pride differs between employees who often have direct experiences with the corporate brand (divisions closer to products) and those with only a few or no direct corporate brand experiences (divisions far from products), or if tenure would have an effect. Here, such a difference would most likely result from a habituation effect, which occurs when a stimulus is often repeated, and thus, becomes familiar (Horn \& Hinde, 1970). Together, the test results for group differences revealed no influence regarding individuals working in a product-related division or on the path between DCBE 
(or even ICBE) and emotional brand pride, making habituation seem unlikely. Another possible explanation for why DCBE could not be confirmed is that such experience is inherently personal, and two individuals cannot have the same DCBE (Pine \& Gilmore, 1998). Decrop and Derbaix (2010, p. 587) argue that 'pride is presented as an achievement-related effect that arises when the achievement is publicly complimented by others'. Similarly, Helm et al. (2016) suggest that corporate brand pride is instigated by a reflected judgement, that is, when others find that something exceeds expectations. Thus, this research suggests that the reflected judgement about the corporate brand by external sources is more important than the subjective experience of the product. However, the nature of DCBE can be seen as strictly personal and 'private', something in the mind of an individual who has embarked on the experience at an emotional, physical, intellectual or spiritual level (Pine \& Gilmore, 1998). For example, with ICBE, if a product that has repeatedly won a prize is announced by internal communication, employees may assume this is known within or even outside the company. However, if the employees experience the product, for example, by driving an automobile (DCBE), they can hardly share this experience with others. Similarly, Pine and Gilmore (1998, p. 99) assume that 'experiences are inherently personal, only in the mind of an individual [...] and the individual's state of mind'. Therefore, ICBE may trigger corporate brand pride more than DCBE does, as other people can perceive and judge ICBE (rather than the 'feeling' of using a product). In addition, past research examined that (corporate) brand experiences differ in terms of strength and intensity (Brakus et al., 2009, Zarantonello \& Schmitt, 2013). Besides the potential causes of differing effects of ICBE and DCBE it can also be that values are more crucial to employees compared to the solely experience of a (corporate) brand's product. This assumption is in line with the social identity theory, which explains how and why people categorize themselves into different social categories. In doing so, employees weight values as significant when these are significant to them self. Therefore, it can be assumed that employees perceive the corporate brand experience through indirect forms stronger, as it is related to their personal values.

Another noteworthy contribution is that corporate brand pride is a strong motivational force that triggers positive employee behaviors such as WOM or employee referrals. Results reveal that differences exist between men and women, in that proud women tend to engage more in employee referrals.

The findings extend AET, demonstrating that work events can either be direct or indirect. In doing so, this paper is the first to differentiate between diverse types of work events. This differentiation is in line with AET research and defines work events as general incidents that stimulate an emotional reaction to a job-related agent, object or event (Basch \& Fisher, 2000). The distinction between various types of work events enables novel options for reasoning, especially for consumer research (studies investigating direct customer encounters in a store and indirect stimulus with the brand).

Although this study provides essential insights, further research is required to overcome its limitations. First, the use of employees from only a single country (Germany) restrains the worldwide generalisability. Here, further studies can include cultural dimensions for example 'collectivism - individualism' to provide an explanation for whether the perception of (product) corporate brand experience differs across cultures. Thereby, collectivistic cultures might focus more on collectivistic forms of (brand) pride (Inglehart \& Baker, 2000). Second, experience with one corporate brand was examined, which may be a limitation, since many companies have now adopted multiple brand strategies. Thus, further research should investigate pride's influence on sub-brands. Like the concept of multiple commitments (Baruch \& Winkelmann-Gleed, 2002), further research could investigate whether employees would be proud of different brands in a multi-brand company, such as Volkswagen. Third, the influence of dispositions was neglected in our research as postulated by AET regarding the relationship of work events and affective experiences. Therefore, future research should include dispositions like the main dimensions of the Big Five personality traits (Borkenau \& Ostendorf, 1991). Fourth, prospective studies regarding (corporate) brand experience should include various forms of emotions (e. g. trust) - examining differences in the way multiple (corporate) brand experience are perceived by employees. Finally, similar to recent research regarding multiple commitments (Baruch \& Winkelmann-Gleed, 2002), future related studies should incorporate multiple forms of pride. Since this paper is the first to empirically assess the effects of corporate brand experience in an employee context and research on employee emotions is still scarce, this paper calls for further research regarding those topics. For example, further research could investigate whether negative corporate brand experiences explicitly decrease employees' brand pride. In addition, further research is required to investigate the nature of DBCE and ICBE. Thus, future research could test whether employees are prouder after truly experiencing the respective product in an experimental setting. This could, for example, be tested similarly as the so-called 'car clinics', where car manufacturers present their novel cars to a peer group and determine how this group experiences the product. Accordingly, products could be presented and tested by employees, and their pride level could be measured before and after the experience. 


\section{Managerial Implications}

The corporate brand experience scale and further insights of the second study will not only be useful for academic research but also for marketing and human resource management practices. In fact, many (corporate) brands and corporations face difficulties finding qualified employees. Numerous studies on human resource management have addressed this topic, highlighting central drivers for attracting and retaining talents (van Hoye \& Lievens, 2007). From this perspective, this research provides insights showing that corporate brand pride plays a central role in turning employees into brand champions. Furthermore, it is showed that corporate brand pride is an important constructs as employees who exhibit higher levels of corporate brand pride engage more often in talking positively about the corporate brand and specifically refer jobs with that corporate brand to friends and acquaintances, which is an important factor because employee referrals represent a crucial hiring source Bloemer (2010). Moreover, study 2 clearly shows that managers play an important role in the creation of ICBE. Managers have an especially important role as they are simultaneously enablers and part of the ICBE. Hence, this research contributes to a better understanding of their specific roles, highlighting that they should promote and exemplify the values of the corporate brand to create a unique corporate brand experience. At the same time, they should foster the exchange of brand-related information between their team members. This finding is in line with the theoretical work of Burmann and König (2011) who stated that brand-oriented empowerment and brand knowledge dissemination are important for brand building.

This research clearly shows that the marketing management should focus on the creation of ICBE using internal and external communications. By doing so, the marketing management can promote the brand values via the Internet, intranet or social media. The findings are especially interesting for marketing management practitioners as the creation of a corporate brand experience is often expensive and resources are generally limited. As such, this paper will contribute to decision making, where one should invest in the ICBE facets than in the DCBE ones.

Although no significant relationship between DCBE and corporate brand pride was found, this paper shows that DCBE positively correlates with brand-supporting behaviours. For this reason, the marketing management of a corporate brand should also include DCBE in their strategies, and for example, create possibilities for employees to experience the corporate brand products - whether in an occupational or private context. Interestingly, some (corporate) brands already recognised the power of experience in relation to their employees. For instance, in 2004, BMW built a 'brand experience centre' where external and internal stakeholders can experience the brand product attributes.

\section{Acknowledgments}

There are no affiliations with or involvement in any organization or entity with any financial interest or nonfinancial interest in the subject matter or materials discussed in this manuscript. This study did not receive any specific grants from funding agencies in the public, commercial or non-profit sectors.

\section{References}

Ambler, T., \& Barrow, S. (1996) The Employer Brand. Journal of Brand Management, 4(3), 185-206. https://doi.org/10.1057/bm.1996.42

Andreini, D., Pedeliento, G., Zarantonello, L., \& Solerio, C. (2018) A Renaissance of Brand Experience: Advancing the Concept Through a Multi - Perspective Analysis. Journal of Business Research, 91, 123133. https://doi.org/10.1016/j.jbusres.2018.05.046

Arnett, D. B., Laverie, D. A., \& Mclane, C. (2002). Using Job Satisfaction and Pride as Internal-marketing Tools. Cornell Hospitality Quarterly, 43(2), 87-96. https://doi.org/10.1177/001088040204300209

Backhaus, K. (2016) Employer Branding Revisited. Organization Management Journal, 13(4), 193-201. https://doi.org/10.1080/15416518.2016.1245128

Bagozzi, R. P., \& Yi, Y. (1988) On the Evaluation of Structural Equation Models. Journal of the Academy of Marketing Science, 16(1), 74-94. https://doi.org/10.1007/BF02723327

Baruch, Y., \& Winkelmann-Gleed, A. (2002) Multiple Commitments: A Conceptual Framework and Empirical Investigation in a Community Health Service Trust. British Journal of Management, 13(4), 337-357. https://doi.org/10.1111/1467-8551.00250

Basch, J., \& Fisher, C. D. (2000) Affective Events-Emotions Matrix: A Classification of Work Events and Associated Emotions. In: N. M. Ashkanasy, C. E. J. Härtel and W.J. Zerbe (Eds.), Emotions in the Workplace: Research, Theory, and Practice (pp. 36-48). Westport, Conn.: Quorum Books。 
Baumgarth, C., \& Schmidt, M. (2010). How Strong is the Business-to-Business Brand in the Workforce? An Empirically-Tested Model of 'Internal Brand Equity' in a Business-to-Business Setting. Industrial Marketing Management. 39(8), 1250-1260. https://doi.org/10.1016/j.indmarman.2010.02.022

Becker, J. M., Klein, K., \& Wetzels, M. (2012) Hierarchical Latent Variable Models in PLS-SEM: Guidelines for Using Reflective-Formative Type Models. Long Range Planning, 45(5-6), 359-394. https://doi.org/10.1016/j.lrp.2012.10.001

Biedenbach, G., \& Marell, A. (2010) The Impact of Customer Experience on Brand Equity in a Business-toBusiness Services Setting. Journal of Brand Management, 17(6), 446-458. https://doi.org/10.1057/bm.2009.37

Bloemer, J. (2010). The Psychological Antecedents of Employee Referrals. The International Journal of Human Resource Management, 21(10), 1769-1791. https://doi.org/10.1080/09585192.2010.500494

Borkenau, P., \& Ostendorf, F. (1991). Ein Fragebogen zur Erfassung fünf robuster Persönlichkeitsfaktoren. Diagnostica.

Brakus, J. J., Schmitt, B. H., \& Zarantonello, L. (2009) Brand Experience: What Is It? How Is It Measured? Does It Affect Loyalty? Journal of Marketing, 73(3), 52-68. https://doi.org/10.1509/jmkg.73.3.52

Breckler, S. J., \& Wiggins, E. C. (1989) Affect Versus Evaluation in the Structure of Attitudes. Journal of Experimental Social Psychology, 25(3), 253-271. https://doi.org/10.1016/0022-1031(89)90022-X

Brosi, P., Spörrle, M., \& Welpe, I. M. (2018). Do we Work Hard or are we Just Great? The Effects of Organizational Pride Due to Effort and Ability on Proactive Behavior. Business Research, 1-17. https://doi.org/10.1007/s40685-018-0061-7

Burmann, C., \& König, V. (2011) Does Internal Brand Management really drive Brand Commitment in SharedService Call Centers? Journal of Brand Management, 18(6), 374-393. https://doi.org/10.1057/bm.2010.50

Burmann, C., Zeplin, S., \& Riley, N. (2009) Key Determinants of Internal Brand Management Success: An Exploratory Empirical Analysis. Journal of Brand Management, 16(4), 264-284. https://doi.org/10.1057/bm.2008.6

Chiang, H. H., Chang, A., Han, T. S., \& Mcconville, D. (2013) Corporate Branding, Brand Psychological Ownership and Brand Citizenship Behaviour: Multilevel Analysis and Managerial Implications. Journal of General Management, 39(1), 55-80. https://doi.org/10.1177/030630701303900104

Chin, W. W. (1998). Issues and Opinion on Structural Equation Modeling. MIS Quarterly, 22(1), 7-16.

Chin, W. W. (2010). How to Write Up and Report PLS Analyses. In: V. Esposito Vinzi (Ed.), Handbook of Partial Least Squares: Concepts, Methods and Applications (pp. 655-690). https://doi.org/10.1007/978-3-54032827-8_29

Chin, W. W., Marcolin, B. L., \& Newsted, P. R. (2003) A Partial Least Squares Latent Variable Modeling Approach for Measuring Interaction Effects: Results from a Monte Carlo Simulation Study and an ElectronicMail Emotion/Adoption Study. Information Systems Research, 14(2), 189-217. https://doi.org/10.1287/isre.14.2.189.16018

Churchill, G. A. (1979) A Paradigm for Developing Better Measures of Marketing Constructs. Journal of Marketing Research, 16(1), 64-73. https://doi.org/10.1177/002224377901600110

Cliffe, S. J., \& Motion, J. (2005) Building Contemporary Brands: A Sponsorship-Based Strategy. Journal of Business Research, 58(8), 1068-1077. https://doi.org/10.1016/j.jbusres.2004.03.004

Crawford, J. A., \& Kelder, J. A. (2018) Do we Measure Leadership Effectively? Articulating and Evaluating Scale Development Psychometrics for Best Practice. The Leadership Quarterly. https://doi.org/10.1016/j.leaqua.2018.07.001

Decrop, A., \& Derbaix, C. (2010). Pride in Contemporary Sport Consumption: A Marketing Perspective. Journal of the Academy of Marketing Science, 38(5), 586-603. https://doi.org/10.1007/s11747-009-0167-8

Edwards, M. R., \& Edwards, T. (2013) Employee Responses to Changing Aspects of the Employer Brand Following a Multinational Acquisition: A Longitudinal Study. Human Resource Management, 52(1), $27-54$. https://doi.org/10.1002/hrm.21519 
Fabrigar, L. R., Wegener, D. T., MacCallum, R. C., \& Strahan, E. J. (1999) Evaluating the use of exploratory factor analysis in psychological research. Psychological Methods, 4(3), 272-299. https://doi.org/10.1037/1082-989X.4.3.272

Field, A. (2005). Discovering Statistics Ssing SPSS. England: SAGE.

Fornell, C., \& Cha, J. (1994). Partial Least Squares. In: R.P. Bagozzi (Ed.), Advanced Methods of Marketing Research (pp. 52-78). Cambridge, Mass.: Blackwell Business,

Fornell, C., \& Larcker, D. F. (1981). Evaluating Structural Equation Models with Unobservable Variables and Measurement Error. Journal of Marketing Research, 18(1), 39-50. https://doi.org/10.1177/002224378101800104

Gouthier, M. H. J., \& Rhein, M. (2011) Organizational Pride and its Positive Effects on Employee Behavior. Journsal of Service Management, 22(5), 633-649. https://doi.org/10.1108/09564231111174988

Hair, Hult, T., Ringle, C., Sarstedt, M., Richter, N., \& Hauff, S. (2017). Partial Least Squares Strukturgleichungsmodellierung (PLS-SEM), Eine anwendungsorientierte Einführung. https://doi.org/10.15358/9783800653614

Hair, J. F., Black, W. C., \& Babin, B. J. (2010) Multivariate Data Analysis: A Global Perspective. Pearson Education.

Hair, J. F., Hult, G. T. M., Ringle, C., \& Sarstedt, M. (2013) A Primer on Partial Least Squares Structural Equation Modeling (PLS-SEM). Sage Publications.

Hair, J. F., Sarstedt, M., Ringle, C. M., \& Mena, J. A. (2012) An Assessment of the Use of Partial Least Squares Structural Equation Modeling in Marketing Research. Journal of the Academy of Marketing Science, 40(3), 414-433. https://doi.org/10.1007/s11747-011-0261-6

Hamzah, Z. L., Syed Alwi, S. F., \& Othman, M. N. (2014) Designing Corporate Brand Experience in an Online Context: A qualitative insight. Journal of Business Research, 67(11), 2299-2310. https://doi.org/10.1016/j.jbusres.2014.06.018

Helm, S. (2012). A Matter of Reputation and Pride: Associations between Perceived External Reputation, Pride in Membership, Job Satisfaction and Turnover Intentions. British Journal of Management, 24(4), 542-556. https://doi.org/10.1111/j.1467-8551.2012.00827.x

Helm, S. V., Renk, U., \& Mishra, A. (2016) Exploring the Impact of Employees' Self-Concept, Brand Identification and Brand Pride on Brand Citizenship Behaviors. European Journal of Marketing, 50(1/2), 5877. https://doi.org/10.1108/EJM-03-2014-0162

Henseler, J., Ringle, C. M., \& Sarstedt, M. (2015) A New Criterion for Assessing Discriminant Validity in Variance-Based Structural Equation Modeling. Journal of the Academy of Marketing Science, 43(1), 115135. https://doi.org/10.1007/s11747-014-0403-8

Herrbach, O., \& Mignonac, K. (2004). How Organisational Image Affects Employee Attitudes. Human Resource Management Journal, 14(4), 76-88. https://doi.org/10.1111/j.1748-8583.2004.tb00134.x

Hoch, S. J. (2002). Product Experience Is Seductive. Journal of Consumer Research, 29(3), 448-454. https://doi.org/10.1086/344422

Holbrook, M. B. (2000). The Millennial Consumer in the Texts of Our Times: Experience and Entertainment. Journal of Macromarketing, 20(2), 178-192. https://doi.org/10.1177/0276146700202008

Homburg, C., \& Pflesser, C. (2000). A Multiple-Layer Model of Market-Oriented Organizational Culture: Measurement Issues and Performance Outcomes. Journal of Marketing Research, 37(4), 449-462. https://doi.org/10.1509/jmkr.37.4.449.18786

Horn, G., \& Hinde, R. A. (1970). Short-Term Changes in Neural Activity and Behaviour: A Conference Sponsored by King's College Research Centre. Cambridge [England]: University Press.

Hui, M. K., \& Bateson, J. E. G. (1991). Perceived Control and the Effects of Crowding and Consumer Choice on the Service Experience. Journal of Consumer Research, 18(2), 174. https://doi.org/10.1086/209250

Iglesias, O., Markovic, S., \& Rialp, J. (2019). How Does Sensory Brand Experience Influence Brand Equity? Considering the Roles of Customer Satisfaction, Customer Affective Commitment, and Employee Empathy. Journal of Business Research, 96, 343-354. https://doi.org/10.1016/j.jbusres.2018.05.043 
Iglesias, O., Singh, J. J., \& Batista-Foguet, J. M. (2011). The Role of Brand Experience and Affective Commitment in Determining Brand Loyalty. Journal of Brand Management, 18(8), 570-582. https://doi.org/10.1057/bm.2010.58

Inglehart, R., \& Baker, W. E. (2000). Modernization, Cultural Change, and the Persistence of Traditional Values. American Sociological Review, 65(1), 19-51. https://doi.org/10.2307/2657288

Jarvis, C. B., MacKenzie, S. B., \& Podsakoff, P. M. (2003). A Critical Review of Construct Indicators and Measurement Model Misspecification in Marketing and Consumer Research. Journal of Consumer Research, 30(2), 199-218. https://doi.org/10.1086/376806

Kempf, D. S., \& Smith, R. E. (1998). Consumer Processing of Product Trial and the Influence of Prior Advertising: A Structural Modeling Approach. Journal of Marketing Research, 35(3), 325. https://doi.org/10.2307/3152031

Kerin, R.A., Jain, A., \& Howard, D.J. (1992). Store Shopping Experience and Consumer Price-Quality-Value Perceptions. Journal of Retailing, 68(4), 376.

Klein, J. F., Falk, T., Esch, F. R., \& Gloukhovtsev, A. (2016). Linking Pop-Up Brand Stores to Brand Experience and Word of Mouth: The case of luxury retail. Journal of Business Research, 69(12), 5761-5767. https://doi.org/10.1016/j.jbusres.2016.04.172

Kraemer, T., \& Gouthier, M. H. J. (2014). How Organizational Pride and Emotional Exhaustion Explain Turnover Intentions in Call Centers. Journal of Service Management, 25(1), 125-148. https://doi.org/10.1108/JOSM07-2013-0173

Kraemer, T., Gouthier, M. H. J., \& Heidenreich, S. (2016). Proud to Stay or Too Proud to Stay?: How Pride in Personal Performance Develops and How It Affects Turnover Intentions. Journal of Service Research, 20(2), 152-170. https://doi.org/10.1177/1094670516673158

Kraemer, T., Weiger, W. H., Gouthier, M. H. J., \& Hammerschmidt, M. (2020). Toward a Theory of Spirals: The Dynamic Relationship Between Organizational Pride and Customer-Oriented Behavior. Journal of the Academy of Marketing Science, 48(6), 1095-1115. https://doi.org/10.1007/s11747-019-00715-0

Lea, S. E. G., \& Webley, P. (1997). Pride in Economic Psychology. Journal of Economic Psychology, 18(2-3), 323-340. https://doi.org/10.1016/S0167-4870(97)00011-1

Lindell, M. K., \& Whitney, D. J. (2001). Accounting for Common Method Variance in Cross-Sectional Research Resigns. Journal of Applied Psychology, 86(1), 114-121. https://doi.org/10.1037/0021-9010.86.1.114

Lohmöller, A. (1989). Latent Path Modelling with Partial Least Squares. Heidelberg: https://doi.org/10.1007/9783-642-52512-4

Löhndorf, B., \& Diamantopoulos, A. (2014). Internal Branding: Social Identity and Social Exchange Perspectives on Turning Employees into Brand Champions. Journal of Service Research. https://doi.org/10.1177/1094670514522098

Lythreatis, S., Mostafa, A. M. S., \& Wang, X. (2019). Participative Leadership and Organizational Identification in SMEs in the MENA Region: Testing the Roles of CSR Perceptions and Pride in Membership. Journal of Business Ethics, 156(3), 635-650. https://doi.org/10.1007/s10551-017-3557-8

Matta, F. K., Erol-Korkmaz, H. T., Johnson, R. E., \& Biçaksiz, P. (2014). Significant Work Events and Counterproductive Work Behavior: The role of fairness, emotions, and emotion regulation. Journal of Organizational Behavior, 35(7), 920-944. https://doi.org/10.1002/job.1934

Meyer, C., \& Schwager, A. (2007). Understanding Customer Experience. Harvard Business Review, 85(2), 116126.

Morgan-Thomas, A., \& Veloutsou, C. (2013). Beyond Technology Acceptance: Brand Relationships and Online Brand Experience. Journal of Business Research, 66(1), 21-27. https://doi.org/10.1016/j.jbusres.2011.07.019

Morhart, F. M., Herzog, W., \& Tomczak, T. (2009). Brand-Specific Leadership: Turning Employees into Brand Champions. Journal of Marketing, 73(5), 122-142. https://doi.org/10.1509/jmkg.73.5.122

Morrison, E. W., \& Robinson, S. L. (1997). When Employees Feel Betrayed: A Model of How Psychological Contract Violation Develops. Academy of Management Review, 22(1), 226-256. https://doi.org/10.2307/259230 
Mosley, R. (2007). Customer Experience, Organisational Culture and the Employer Brand. Journal of Brand Management, 15(2), 123-134. https://doi.org/10.1057/palgrave.bm.2550124

Nedkovski, V., Guerci, M., Battisti, F., \& Siletti, E. (2017). Organizational Ethical Climates and Employee's Trust in Colleagues, the Supervisor, and the Organization. Journal of Business Research, 71, 19-26. https://doi.org/10.1016/j.jbusres.2016.11.004

Nunnally, J. C. (1978). Psychometric Theory. New York: McGraw-Hill.

Nysveen, H., \& Pedersen, P. E. (2015). Influences of Co-Creation on Brand Experience: The role of brand engagement. International Journal of Market Research, 56(6), 807. https://doi.org/10.2501/IJMR-2014-016

Pearlman, D. (2010). Mercedes- Benz Internal Branding. Retrieved from http://danpearlman.com/work/markenstrategie-mercedes-benz-internal-branding/

Piehler, R., King, C., Burmann, C., \& Xiong, L. (2016). The Importance of Employee Brand Understanding, Brand Identification, and Brand Commitment in Realizing Brand Citizenship Behaviour. European Journal of Marketing 50(9/10), 1575-1601. https://doi.org/10.1108/EJM-11-2014-0725

Pine, B. J., \& Gilmore, J. H. (1998). Welcome to the Experience Economy. Harvard Business Review, 76, 97-105.

Podsakoff, P.M., MacKenzie, S.B., Lee, J. Y., \& Podsakoff, N.P. (2003). Common Method Biases in Behavioral Research: A Critical Review of the Literature and Recommended Remedies. The Journal of Applied Psychology 88(5), 879-903. https://doi.org/10.1037/0021-9010.88.5.879

Punjaisri, K., \& Wilson, A. (2011). Internal Branding Process: Key Mechanisms, Outcomes and Moderating Factors. European Journal of Marketing, 45(9/10), 1521-1537. https://doi.org/10.1108/03090561111151871

Punjaisri, K., Wilson, A., \& Evanschitzky, H. (2008). Exploring the Influences of Internal Branding on Employees' Brand Promise Delivery: Implications for Strengthening Customer-Brand Relationships. Journal of Relationship Marketing, 7(4), 407-424. https://doi.org/10.1080/15332660802508430

Rampl, L. V., Opitz, C., Welpe, I. M., \& Kenning, P. (2014). The Role of Emotions in Decision-Making on Employer Brands: Insights From Functional Magnetic Resonance Imaging (fMRI). Marketing Letters, 1-14. https://doi.org/10.1007/s11002-014-9335-9

Ritzenhöfer, L., Brosi, P., Spörrle, M., \& Welpe, I. M. (2019). Satisfied with the Job, But Not with the Boss: Leaders' Expressions of Gratitude and Pride Differentially Signal Leader Selfishness, Resulting in Differing Levels of Followers' Satisfaction. Journal of Business Ethics 158(4), 1185-1202. https://doi.org/10.1007/s10551-017-3746-5

Roth, P. L., SwitzerIII, F. S., \& Switzer, D. M. (1999). Missing Data in Multiple Item Scales: A Monte Carlo Analysis of Missing Data Techniques. Organizational Research Methods, 2(3), 211-232. https://doi.org/10.1177/109442819923001

Schouten, J. W., McAlexander, J. H., \& Koenig, H. F. (2007). Transcendent Customer Experience and Brand Community. Journal of the Academy of Marketing Science, 35(3), 357-368. https://doi.org/10.1007/s11747007-0034-4

Turhan, M. (2014). Organizational cConyism: A Scale Development and Validation From the Perspective of Teachers. Journal of Business Ethics, 123(2), 295-308. https://doi.org/10.1007/s10551-013-1839-3

van Hoye, G., \& Lievens, F. (2007). Investigating Web-Based Recruitment Sources: Employee testimonials vs word-of-mouse. Inernational Journal of Selection and Assessment, 15(4), 372-382. https://doi.org/10.1111/j.1468-2389.2007.00396.x

Verbeke, W. (2004). The Adaptive Consequences of Pride in Personal Selling. Journal of the Academy of Marketing Science, 32(4), 386-402. https://doi.org/10.1177/0092070304267105

Verhoef, P. C., Lemon, K. N., Parasuraman, A., Roggeveen, A., Tsiros, M., \& Schlesinger, L. A. (2009). Customer Experience Creation: Determinants, Dynamics and Management Strategies. Journal of Retailing, 85(1), 3141. https://doi.org/10.1016/j.jretai.2008.11.001

Weiss, H. M. (2002). Deconstructing Job Satisfaction. Human Resource Management Review, 12(2), 173-194. https://doi.org/10.1016/S1053-4822(02)00045-1

Weiss, H. M., \& Cropanzano, R. (1996). Affective Events Theory: A Theoretical Discussion of the Structure, Causes and Consequences of Affective Experiences at Work. Research in Organizational Behavior, 18, 174. 
Zarantonello, L., \& Schmitt, B. H. (2010). Using the Brand Experience Scale to Profile Consumers and Predict Consumer Behaviour. Journal of Brand Management, 15(7), 532-540. https://doi.org/10.1057/bm.2010.4

Zha, D., Melewar, T. C., Foroudi, P., \& Jin, Z. (2020). An Assessment of Brand Experience Knowledge Literature: Using Bibliometric Data to Identify Future Research Direction. International Journal of Management Reviews, 22(3), 287-317. https://doi.org/10.1111/ijmr.12226

Zhao, X., Lynch, J. G., \& Chen, Q. (2010). Reconsidering Baron and Kenny: Myths and Truths about Mediation Analysis. Journal of Consumer Research, 37(2), 197-206. https://doi.org/10.1086/651257

\section{Copyrights}

Copyright for this article is retained by the author(s), with first publication rights granted to the journal.

This is an open-access article distributed under the terms and conditions of the Creative Commons Attribution license (http://creativecommons.org/licenses/by/4.0/). 